Biogeosciences Discuss., doi:10.5194/bg-2017-93, 2017

Manuscript under review for journal Biogeosciences

Discussion started: 22 March 2017

(C) Author(s) 2017. CC-BY 3.0 License.

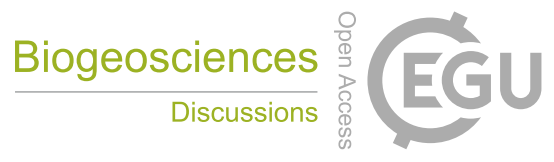

(c) (1)

\title{
1 Optical and molecular-level characterization of fluvial organic 2 matter biodegradation in a highly urbanized river system
}

3 Most Shirina Begum ${ }^{1}$, Hyojin Jin ${ }^{1}$, Inae Jang ${ }^{2}$, Jung-Min Lee ${ }^{2}$, Han Bin Oh ${ }^{2}$, Ji-Hyung Park ${ }^{1}$

$4 \quad{ }^{1}$ Department of Environmental Science \& Engineering, Ewha Womans University, Seoul 03760, Republic of Korea

$5 \quad 2$ Department of Chemistry, Sogang University, Seoul 04107, Republic of Korea

6 Correspondence to: Ji-Hyung Park (jhp@ewha.ac.kr); Han Bin Oh (hanbinoh@sogang.ac.kr) 
Biogeosciences Discuss., doi:10.5194/bg-2017-93, 2017

Manuscript under review for journal Biogeosciences

Discussion started: 22 March 2017

(c) Author(s) 2017. CC-BY 3.0 License.

Abstract. Rapid urbanization worldwide is changing both the transport of organic matter $(\mathrm{OM})$ and $\mathrm{CO}_{2}$ emission in urban streams and rivers, yet little is known as to how the altered quality of riverine $\mathrm{OM}$ affects biodegradation and $\mathrm{CO}_{2}$ emission. The relationships between the chemical properties and biodegradation of riverine OM, including dissolved and particulate OM (DOM and POM), were examined against the level of anthropogenic perturbation along the Han River, a river system in South Korea that has been highly modified by dams and urban water pollution. DOM optical properties and biodegradable dissolved organic carbon (BDOC), together with in situ measurements of the partial pressure of $\mathrm{CO}_{2}\left(p \mathrm{CO}_{2}\right)$ using a membrane-enclosed sensor, were compared between the up-, mid-, and downstream reaches of the Han River and three urban tributaries in a basin-scale field campaign combined with a 7 day incubation of both filtered and unfiltered samples. Another 5 day incubation was conducted with unfiltered water samples from a downstream river site and an urban tributary, in isolation and mixed (1:1), to measure changes in dissolved $\mathrm{CO}_{2}$ concentrations at 10-min intervals and BDOC and optical properties at intervals of 1-2 days. Fourier transform-ion cyclotron resonance-mass spectrometry (FT-ICR-MS) was used to detect molecular-level changes in DOM composition between the initial and post-incubation samples. The average BDOC concentration in the urban tributaries was 4-12 times higher than those of three mainstem reaches, while BDOC was highly variable at three downstream sites and tended to be higher at the mainstem sites affected by agricultural runoff or dams than at the forested headwater stream. Longitudinal increases in protein-like and "microbial" humic-like fluorescence, fluorescence index (FI), and biological index (BIX) reflected increasing inputs of anthropogenic DOM along the downstream reach and urban tributaries. These optical indices, along with $p \mathrm{CO}_{2}$, were significantly correlated with BDOC concentrations measured at 12 sites. The cumulative $\mathrm{CO}_{2}$ production measured in the second incubation was greatest in the mixture, followed by the urban tributary and mainstem samples in the descending order. The amount of $\mathrm{CO}_{2}$ produced in the mixture was greater than the $\mathrm{BDOC}$ measured in the same sample or the average of $\mathrm{CO}_{2}$ produced in the separate samples, indicating a mixing-enhanced biodegradation of DOM including the fraction transformed from soluble components of POM. FT-ICR-MS analysis revealed a much larger number of molecules consumed (3984) than those produced (771) during the incubation of the mainstem sample in contrast to the produced molecules (2789) exceeding the consumed molecules (1479) in the tributary sample, indicating a high rate of OM processing in the urban tributary that might be limited in the availability of immediately consumable organic materials. Overall results suggest that water pollution, along with impoundment effects of dams, can alter the optical properties and biodegradability of both DOM and POM in highly 
Biogeosciences Discuss., doi:10.5194/bg-2017-93, 2017

Manuscript under review for journal Biogeosciences

Discussion started: 22 March 2017

(c) Author(s) 2017. CC-BY 3.0 License.

Key words: biodegradation; $\mathrm{CO}_{2}$ emission; dissolved organic matter; fluorescence EEMs; FT-ICR-MS; particulate organic

matter; urbanized watershed; water pollution

\section{Introduction}

Inland waters, as a crucial component of the global carbon cycle, can provide a positive feedback to climate change, because active transformations of organic matter $(\mathrm{OM})$ of both terrestrial and aquatic origin during transit to the oceans result in large emissions of $\mathrm{CO}_{2}$ and $\mathrm{CH}_{4}$ (Aufdenkampe et al., 2011; Bastviken et al., 2013; Cole et al., 2007; Raymond et al., 2013; Wehrli, 2013). Transformations of OM in inland waters can be affected by concurrent changes in climatic conditions, agricultural activities, water impoundments, and other anthropogenic modifications of water flow and quality in increasingly urbanizing watersheds worldwide (Casas-Ruiz et al., 2016; Hutyra et al., 2014; Kaushal et al., 2014; Parr et al., 2015; Regnier et al., 2013). In eutrophic inland waters receiving high loads of anthropogenic OM, enhanced transformations of $\mathrm{OM}$ and subsequent changes in chemical characteristics have been explored by employing various OM characterization techniques including absorbance and fluorescence measurements (Abril et al., 2002; Baker, 2001; Hosen et al., 2014; Williams et al., 2016; Wilson and Xenopoulos, 2009). Increased biodegradability in urbanized watersheds has been linked to increased inputs of labile OM from anthropogenic sources and an associated potential enhancement of the biodegradation of natural organic materials (Guo et al., 2014; Knapik et al., 2015; Parr et al., 2015). Recent studies have quantified and characterized increasing loads of dissolved OM (DOM) in urbanized rivers and estuaries (Guo et al., 2014; Hosen et al., 2014; McElmurry et al., 2014; Parr et al., 2015). However, the characterization of DOM has rarely been associated with altered rates of greenhouse gas (GHG) emissions from urbanized river systems (Kaushal et al., 2014).

Optical characterization of DOM has been used to examine land use effects on the quality of DOM in streams and rivers draining agricultural lands (Petrone et al., 2011; Wilson and Xenopoulos, 2009) and urban population centers (Hosen et al., 2014; McElmurry et al., 2014). DOM absorbance and related indices such as specific absorbance at $254 \mathrm{~nm}\left(\mathrm{SUVA}_{254}\right)$, absorbance coefficients based on absorbance measurements at $254 \mathrm{~nm}\left(a_{254}\right)$ and $350 \mathrm{~nm}\left(a_{350}\right)$, spectral slopes over the ranges of 275-295 $\mathrm{nm}\left(S_{275-295}\right)$ and 350-400 $\mathrm{nm}\left(S_{350-400}\right)$ and slope ratio $\left(S_{\mathrm{R}}\right)$ have frequently been used as efficient tools for optical characterization of DOM (Helms et al., 2008; Spencer et al., 2012). Fluorescence excitation-emission matrices (EEMs) can visualize fluorescent DOM (FDOM) components that can indicate the source and biodegradability of DOM (Baker, 2001; Osburn et al., 2012). Fluorescence indices such as fluorescence index (FI) (McKnight et al., 2001), 
Biogeosciences Discuss., doi:10.5194/bg-2017-93, 2017

Manuscript under review for journal Biogeosciences

Discussion started: 22 March 2017

(c) Author(s) 2017. CC-BY 3.0 License.

humification index (HIX) (Zsolnay et al., 1999), and biological index (BIX) (Huguet et al., 2009; Parlanti et al., 2000), along with various FDOM components including "terrestrial" and "microbial" humic-like fluorescence and protein-like fluorescence and their ratios (Fellman et al., 2010), have been used to examine the source and lability of DOM in a wide range of inland waters. Biodegradable dissolved organic carbon (BDOC) has been shown to increase in urbanized river systems (Knapik et al., 2015; Shi et al., 2016) and agricultural watersheds (Royer and David, 2005; Stanley et al., 2011); however, there have been only a few studies that examined the relationships between BDOC and optical properties of DOM in highly human-modified streams and rivers (e.g., Hur et al., 2014a; Parr et al., 2015). Recent studies have used Fourier transform-ion cyclotron resonance-mass spectrometry (FT-ICR-MS) to provide molecular-level information on compositional changes incurred from DOM biodegradation (Ward et al., 2013), opening a new way to investigate the relationships between the chemical characteristics and biodegradability of DOM.

The priming effect has recently been proposed as a possible explanation for large $\mathrm{CO}_{2}$ emissions from inland water systems and the lack of recalcitrant terrigenous components in marine sediments (Bianchi, 2011; Bianchi et al., 2015). The concept of priming effect was originally used in the study of soil OM to explain enhanced decomposition of recalcitrant organic materials following the addition of labile materials (Kuzyakov et al., 2000). Recent applications to the study of inland waters have provided contrasting results, including negative priming, no priming, and positive priming (Bianchi et al., 2015; Catalan et al., 2015; Guenet et al., 2014; Hotchkiss et al., 2014; Kuehn et al., 2014). Rare efforts have yet been made to examine priming effects of anthropogenic pollution or algal OM produced in impounded reaches in highly modified river systems. Furthermore, previous studies of priming effects on riverine OM biodegradation have not adequately addressed active transformations between DOM and particulate OM (POM) driven by microbial assimilation and degradation (Osburn et al., 2012; Ward et al., 2013). Combining continuous $\mathrm{CO}_{2}$ measurements with BDOC quantification can enable a more accurate assessment of the priming effect induced by inputs of labile OM components (Bianchi et al., 2015). The primary aim of this study was to examine the relationships between optical characteristics and biodegradability of DOM and POM in the Han River watershed, which has a large spatial diversity ranging from the predominantly forested upstream reach through the heavily impounded midstream reach to the highly urbanized downstream reach receiving high loads of anthropogenic OM from urban tributaries. Another goal was to investigate whether priming effects of labile OM of autochthonous or anthropogenic origin can enhance the rate of biodegradation of riverine $\mathrm{OM}$ and hence $\mathrm{CO}_{2}$ emission from 
Biogeosciences Discuss., doi:10.5194/bg-2017-93, 2017

Manuscript under review for journal Biogeosciences

Discussion started: 22 March 2017

(c) Author(s) 2017. CC-BY 3.0 License.

more detailed understanding of how downstream changes in riverine OM quality driven by dams and urban water pollution can enhance the biodegradation of DOM, with and without POM, either in the field or in controlled laboratory settings.

\section{Materials and methods (Will be shortened after English editing)}

\subsection{Study site and basin-scale survey}

The Han River basin $\left(36^{\circ} 30^{\prime}\right.$ to $38^{\circ} 55^{\prime} \mathrm{N}$; $126^{\circ} 24^{\prime}$ to $129^{\circ} 02^{\prime}$ E) consists of two main branches - the North Han River and the South Han River - and the lower Han River along the Seoul metropolitan area (Fig. 1) (Chang, 2008; Hur et al., 2014b). Surface water samples were collected along the longitudinal continuum encompassing the North Han River and the lower Han River (Fig. 1; Table S1). The river runs $515 \mathrm{~km}$ along the waist of the Korean Peninsula from the heavily forested headwaters in Gangwon province to the Seoul metropolitan area with more than 25 million residents, draining a total area of $26,018 \mathrm{~km}^{2}$ (Ministry of Environment Korea). In the upstream reach of the North Han River, about $87 \%$ of the watershed is covered with forests, $7 \%$ with agricultural farm lands, and $2 \%$ with residential areas (Kang and Park, 2015; WAMIS). Expansion of agricultural lands on steep mountainous terrain over the recent decades has increased rates of soil erosion, often resulting in large exports of sediments and associated POM during intense storm events (Jung et al., 2015). Along the midstream reach of the North Han River, $68 \%, 13 \%$, and $15 \%$ of the watershed is covered with forests, agricultural farm lands, and residential areas respectively (Kang and Park, 2015; WAMIS, 2006). In addition to the effect of agricultural farm lands, four large dams along the midstream reach of the North Han River affect the water quality by increasing the mean water retention time (Jung et al., 2014; MOLIT, 2016). Along the downstream reach of the Han River from the outflow of the Lake Paldang to the Yellow Sea, forests and agricultural lands each account for about $31 \%$ and the residential areas $25 \%$ of the watershed (Chang, 2008; Kang and Park, 2015; WAMIS). The flow of the lower Han River is strongly affected by discharges from the Lake Paldang and two in-stream weirs constructed in the upper and lower ends of the river section along the city of Seoul (Kang and Park, 2015; Yoon et al., 2010). Three major urban tributaries, together with other small streams, deliver discharges from waste water treatment plants (WWTP) and urban runoffs into the downstream reach of the Han River (Fig. 1).

To examine spatial variations in the optical characteristics and biodegradability of riverine OM across the North Han River basin and the lower Han River, water samples were collected from three upstream, three midstream, and three downstream locations of the Han River, and three urban tributaries along the downstream reach in May 2015 (Fig. 1; Table S1). Spot 
Biogeosciences Discuss., doi:10.5194/bg-2017-93, 2017

Manuscript under review for journal Biogeosciences

Discussion started: 22 March 2017

(c) Author(s) 2017. CC-BY 3.0 License. that were filtered within 1-2 days after sampling, together with unfiltered subsamples, were stored at $4^{\circ} \mathrm{C}$ until chemical analyses including BDOC determination. During water sampling, in situ measurements of the partial pressure of $\mathrm{CO}_{2}\left(p \mathrm{CO}_{2}\right)$ were conducted at the same water depth using a $\mathrm{CO}_{2}$ sensor $\left(\mathrm{CARBOCAP}^{\circledR}\right.$, GMT222, Vaisala, Finland) enclosed in PTFE-membrane (200-07, International Polymer Engineering, USA). The method is described in detail in Yoon et al. (2016). The sensor system includes two $\mathrm{CO}_{2}$ sensors for concurrent measurements of water and atmospheric $p \mathrm{CO}_{2}$, a data logger (CR10X, Campbell Scientific Inc., USA), and three batteries ( $12 \mathrm{~V} 7 \mathrm{AH}$, Rocket, Korea). Before the sampling, the $\mathrm{CO}_{2}$ sensors were calibrated in the laboratory using $\mathrm{CO}_{2}$ standard gases of known concentrations $(0,500,5000,10000 \mathrm{ppm})$. The sensor output was corrected for the ambient pressure; values were increased or decreased by $0.15 \%$ for $1 \mathrm{hPa}$ decrease or increase in pressure from the standard pressure used for calibration, respectively (Johnson et al., 2010). The output was also corrected for temperature: $0.3 \%$ increase or decrease for $1{ }^{\circ} \mathrm{C}$ higher or lower temperature than the standard temperature used for calibration, respectively (Johnson et al., 2010).

\subsection{Seven-day laboratory incubation}

A 7 day laboratory incubation was conducted with the water samples collected at 12 sampling locations along the Han River and urban tributaries (Fig. 1), following the methods modified from Servais et al. (1987) and Wickland et al. (2012). A subset of samples were filtered through pre-combusted glass fiber filters (GF/F, Whatman; nominal pore size $0.7 \mu \mathrm{m})$ to remove POM. Three replicates of the filtered sample $(80 \mathrm{ml})$ were incubated in $120 \mathrm{ml}$ amber glass bottles at $20{ }^{\circ} \mathrm{C}$ (the average water temperature during sampling) in the dark. A small volume (1\% of each incubated water sample) of the original, unfiltered water sample was added as a site-specific inoculum to the respective incubation sample to provide indigenous microorganisms that can degrade DOM components in the filtered water sample. Another batch of unfiltered samples was incubated under the same conditions without addition of any inoculum to compare additional effects of POM on riverine OM biodegradation. To maintain aerobic condition in the closed incubation bottles throughout the incubation period, the bottles were uncapped and gently shaken for 30 min every two days. BDOC was calculated as the difference between the final and initial concentrations of DOC. Another set of samples containing only ultrapure water (Milli-Q, 
Biogeosciences Discuss., doi:10.5194/bg-2017-93, 2017

Manuscript under review for journal Biogeosciences

Discussion started: 22 March 2017

(c) Author(s) 2017. CC-BY 3.0 License.

\subsection{Five-day laboratory incubation}

141 To investigate priming effects of anthropogenic or autochthonous $\mathrm{OM}$ on the biodegradation of riverine $\mathrm{OM}$ in the downstream reach under more realistic water conditions considering both DOM and POM, the second incubation experiment was conducted with unfiltered water samples from an upstream location of the lower Han River, $\sim 20 \mathrm{~km}$ downstream of the Lake Paldang (hereafter termed "mainstem") and an urban tributary, Jungnang Stream (hereafter termed "tributary") (Fig. 1). Samples were collected in acid-washed $20 \mathrm{~L}$ polycarbonate containers in July 2015 from $10-20 \mathrm{~cm}$ below the surface of the mainstem and tributary using a portable water sampler. A mixture sample (hereafter termed "mixture") was prepared by mixing the samples from the Han River mainstem and the urban tributary with a mixing ratio of 1:1. In one experimental set-up, replicates of $60 \mathrm{ml}$ unfiltered samples were placed in acid-washed amber glass bottles (120 $\mathrm{ml})$. The bottles were sealed with butyl septa and aluminum crimps and then incubated for five days, with three bottles per treatment destructively sampled at $0 \mathrm{~h}, 1 \mathrm{~h}, 1$ day, 3 day, and 5 day. A prior test had shown that a larger headspace volume than the first experiment could maintain aerobic condition in the closed bottles for 5 days. Samples were incubated in the dark at $25{ }^{\circ} \mathrm{C}$, which was the average water temperature during the month when water samples were collected. In another experimental set-up, one $10 \mathrm{~L}$ sample per treatment was incubated in $20 \mathrm{~L}$ gas-tight polycarbonate containers; the same $50 \%$ headspace volume was created to maintain aerobic condition within the sealed incubation container. A membraneenclosed $\mathrm{CO}_{2}$ sensor that had been used in the field survey was immersed in each of three samples in order to measure dissolved $\mathrm{CO}_{2}$ in the water at 10 min intervals. The sensor output in $p \mathrm{CO}_{2}$ values were converted to dissolved $\mathrm{CO}_{2}$ concentrations (mg C L ${ }^{-1}$ ) using Henry's constant for dissolved $\mathrm{CO}_{2}$ at standard temperature and pressure (Johnson et al.,

\subsection{Chemical analysis}

Water samples were filtered through pre-combusted glass fiber filters to remove suspended materials. Concentration of total suspended solid (TSS) were measured gravimetrically as the difference in the filter weight before and after filtering and drying at $60{ }^{\circ} \mathrm{C}$ for 48 hours. The concentration of DOC was measured using a total organic carbon (TOC) analyzer using high-temperature combustion of $\mathrm{OM}$ followed by thermal detection of $\mathrm{CO}_{2}$ (TOC- $\mathrm{V}_{\mathrm{CPH}}$, Shimadzu, Japan). As part of 
Biogeosciences Discuss., doi:10.5194/bg-2017-93, 2017

Manuscript under review for journal Biogeosciences

Discussion started: 22 March 2017

(c) Author(s) 2017. CC-BY 3.0 License.

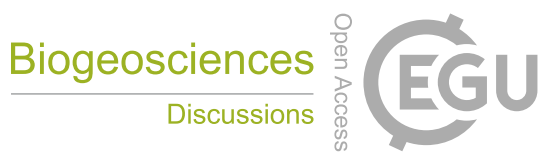

quality control, standards with known DOC concentrations and ultrapure water were analyzed for every batch of ten samples and triplicate analysis was performed for approximately $10 \%$ of all analyzed samples to assess instrumental stability and accuracy.

Fluorescence EEMs were collected on a fluorescence spectrophotometer (F7000, Hitachi, Japan) by simultaneous scanning over excitation wavelengths from 200 to $400 \mathrm{~nm}$ at $5 \mathrm{~nm}$ interval and emission wavelengths from 290 to $540 \mathrm{~nm}$ at $1 \mathrm{~nm}$ interval. Scan speed was $2400 \mathrm{~nm} \mathrm{~min}{ }^{-1}$ and the bandwidth was set to $5 \mathrm{~nm}$ for both excitation and emission. A $290 \mathrm{~nm}$ cutoff filter was used for all the measurements to minimize second-order Rayleigh scattering. Blank run with ultrapure water was conducted at least once for every batch of 10 samples and Raman band intensity at Ex. $350 \mathrm{~nm} / \mathrm{Em} .400 \mathrm{~nm}$ was used to monitor the instrumental stability. Fluorescence intensities of the actual water samples were divided by the Raman band intensity determined prior to sample measurements to correct any fluctuation in instrumental conditions. All the EEMs were corrected for the Rayleigh scattering and inner-filter effect by subtracting the blank measurements from the sample measurements and by using an absorption-based correction equation suggested by Ohno (2002), respectively. UV absorbance was measured across the wavelength range from 200 to $1100 \mathrm{~nm}$ using a UV-Vis spectrophotometer (Agilent 8453, USA).

Optical fluorescence parameters were obtained from the corrected EEMs and absorbance values at the respective wavelengths (Table S2). Optical indices such as HIX (Zsolnay et al., 1999), FI (McKnight et al., 2001), and BIX (freshness index or $\beta: \alpha$ ratio) (Parlanti et al., 2000; Wilson and Xenopoulos, 2009) were obtained from the EEMs (Table S2). Fluorescence intensities of three FDOM components, including "terrestrial" humic-like FDOM (C1) associated with soilderived humic substances, "microbial" humic-like FDOM (C2) indicating autochthonous OM produced by microbial activity, and protein-like FDOM (C3) derived from microbial metabolites of natural or anthropogenic OM were also obtained for the wavelength ranges identified in the same study site and other studies (Table S2; Fellman et al., 2010). In addition, absorption parameters such as $a_{254}, a_{350}, \mathrm{SUVA}_{254}, \mathrm{SUVA}_{350}, S_{275-295}, S_{350-400}$ were determined from UV absorbance measurements (Table S2; Helms et al., 2008; Weishaar et al., 2003).

\subsection{Acquisition and analysis of FT-ICR mass spectra}

Solid phase extraction (SPE) was used to extract DOM from a large volume $(5 \mathrm{~L})$ of the mainstem and tributary samples before and after the 5 day incubation, following Dittmar et al. (2008). The mixture sample was not included due to logistical 
Biogeosciences Discuss., doi:10.5194/bg-2017-93, 2017

Manuscript under review for journal Biogeosciences

Discussion started: 22 March 2017

(c) Author(s) 2017. CC-BY 3.0 License.

constraints. Samples were filtered (GF/F; $0.7 \mu \mathrm{m})$ and acidified to $\mathrm{pH} 2$ using $30 \% \mathrm{HCl}$ right before SPE in order to enhance extraction efficiency. Precipitation of DOM due to acidification was not observed in any of the samples. PPL cartridges (Agilent Technologies Inc., Santa Clara, CA, USA) of $6 \mathrm{ml}$ volume with $1 \mathrm{~g}$ sorbent were used for DOM extraction. Cartridges were rinsed with $12 \mathrm{ml}$ of methanol (99.8\%) and $1 \mathrm{~L}$ of Milli-Q water to remove any potential OM contamination. Samples were passed through the cartridge using a peristaltic pump at a flow rate of 20 to $30 \mathrm{ml} \mathrm{min}^{-1}$. $\mathrm{N}_{2}$ gas was purged slowly to dry the cartridge. DOM was extracted by passing $6 \mathrm{ml}$ of methanol very slowly, approximately at the rate of $1 \mathrm{ml} \mathrm{min}{ }^{-1}$. Samples were collected and stored in a $10 \mathrm{ml}$ glass ampule and stored at $-20{ }^{\circ} \mathrm{C}$ until FT-ICR-MS analysis. Samples were purged with $\mathrm{N}_{2}$ gas to increase the concentration of DOM for FT-ICR-MS analysis.

Ultrahigh resolution mass spectra were acquired using a 15 Tesla Fourier transform ion cyclotron resonance (FT-ICR) mass spectrometer (SolariX, Bruker Daltonics Inc., Billerica, MA, USA), equipped with an Apollo II ion funnel electrospray ionization (ESI) source, at Korea Basic Science Institute (KBSI, Cheongju, Korea). ESI mass spectra of DOM were obtained in negative ion mode. A DOM sample solution dissolved in methanol:water 1:1 (v/v) with $0.1 \%$ ammonium hydroxide (pH 8) was infused continuously at a flow rate of $120 \mu \mathrm{L} \mathrm{h}^{-1}$ using a syringe pump (Harvard Apparatus, Holliston, MA, USA). Drying gas temperature was set to $210{ }^{\circ} \mathrm{C}$ and its flow rate was $4.0 \mathrm{~L} \mathrm{~min}^{-1}$. Electrosprayed ions (spray voltage: $-3.0 \mathrm{kV}$ ) were introduced into the mass spectrometer and externally accumulated for $\sim 0.5 \mathrm{~s}$ in order to increase detected ion abundance, and then transferred to the ICR cell. FT-ICR mass spectra were acquired over 100 time-domain transients at 4 Mword over the mass range of m/z 160/1000 in broadband mode. All the samples were analyzed in triplicates. The summed free induction decay signal was zero-filled once and full-sine apodized prior to fast Fourier transform processing.

FT-ICR MS spectra were calibrated externally and internally using a series of arginine (Sigma, St. Louis, MO, USA) clusters in negative ion mode. The ion peaks were selected with a criterion of $\mathrm{S} / \mathrm{N}$ ratio of $\geq 5$ and a peak list was generated. The ion peaks detected at least two times out of triplicate measurements were included in the peak list. All the detected ions were singly charged (assumed to be deprotonated), which was confirmed by the isotope spacing. The ion peak abundances were normalized with respect to the sum of all the ion abundances. Chemical formula assignment was performed with selfwritten software and database that were coded with MATLAB (MathWorks, Inc., Natick, MA, USA). The home-coded software was rigorously validated using the data provided in the supporting information of Koch et al. (2007). The database was constructed following the stringent criteria with elemental combinations of ${ }^{12} \mathrm{C}_{1-100}{ }^{1} \mathrm{H}_{0-200}{ }^{16} \mathrm{O}_{1-50}{ }^{14} \mathrm{~N}_{0-10}{ }^{31} \mathrm{P}_{0-2}{ }^{32} \mathrm{~S}_{0-2}$. In the database, the chemical formula entities that violate the nitrogen rule and double bond equivalent rule were all eliminated 
Biogeosciences Discuss., doi:10.5194/bg-2017-93, 2017

Manuscript under review for journal Biogeosciences

Discussion started: 22 March 2017

(c) Author(s) 2017. CC-BY 3.0 License.

(Koch et al., 2007; McLafferty and Turecek, 1993). In addition, the chemical formula entities were further selected to meet the following elemental ratio criteria: $0.3<\mathrm{H} / \mathrm{C}<2.25, \mathrm{O} / \mathrm{C}<1.0, \mathrm{~N} / \mathrm{C}<1.0, \mathrm{~S} / \mathrm{C}<0.2, \mathrm{H} \leq 2 \mathrm{C}+\mathrm{N}+\mathrm{P}+2, \mathrm{P} / \mathrm{C} 0.1, \mathrm{~S}+\mathrm{P} / \mathrm{C}<$ $0.2, \mathrm{O} \leq \mathrm{C}+2$ (Koch et al., 2007; Stubbins et al., 2010). The formulas containing $\mathrm{N}_{2} \mathrm{~S}_{2}$ were all removed from the database. Further, when a homologous series with relative peak distances of $36.4 \mathrm{mDa}$ were detected, the so-called "chemical building block" approach was adopted in order to unambiguously assign the ion peaks (Koch et al., 2007). In database search, the mass accuracy limit was set to be less than $1 \mathrm{ppm}$. Van Krevelen plots were drawn using MATLAB software.

\subsection{Statistical analysis}

Paired t-test was performed to identify any significant difference in BDOC concentration and other optical measurements between the filtered and unfiltered samples from the field survey and the first incubation experiment. Paired t-test was also used to identify significant differences in optical measurements between the initial and post-incubation samples. Regression analysis was conducted to establish significant relationships between BDOC and other measurements at 12 sites. Analysis of variance (ANOVA) followed by Tukey's honest significant difference (HSD) was used to examine significant differences among the up-, mid-, and downstream reaches, and the urban tributaries. Normality of data distribution was examined prior to conducting paired t-test and ANOVA and any data sets showing non-normal distribution were normalized by logtransformation of the data. All analyses were conducted on R software environment for statistical computing and graphics (R Development Core Team, 2011). Unless otherwise noted, all reported significance levels were set at $P<0.05$.

\section{Results}

\subsection{Basin-scale spatial patterns of optical properties and biodegradability of DOM and POM}

The $p \mathrm{CO}_{2}$ measured in situ was much higher at two urban tributary sites $(4,342$ and 11,449 $\mu$ atm) than at the river mainstem sites and exhibited downstream increases from the generally low values across the up- and mid-stream sites $(<1,000 \mu$ atm $)$ to the medium-range values at the downstream sites (Fig. 2; Table S3b). The concentrations of BDOC measured during the 7 day incubation with both filtered and unfiltered samples from 12 sites showed distinct spatial patterns (Fig. 2; Table S3). The highest BDOC value was observed for an urban tributary $\left(1.01 \mathrm{mg} \mathrm{C} \mathrm{L}^{-1} ; 20 \%\right.$ of the initial DOC) and the lowest BDOC in the forested headwater stream $\left(0.01 \mathrm{mg} \mathrm{L}^{-1} ; 1.4 \%\right.$ of the initial DOC), with an average \%BDOC of $10 \%$ for all samples. 
Biogeosciences Discuss., doi:10.5194/bg-2017-93, 2017

Manuscript under review for journal Biogeosciences

Discussion started: 22 March 2017

(c) Author(s) 2017. CC-BY 3.0 License. across three mainstem reaches (Fig. 2; Table S3). BDOC concentrations at a midstream (Mid 3 ) and a downstream (Down 2) sites and two urban tributaries (Urban 1,2) were slightly, but significantly higher in the unfiltered samples compared to the filtered samples.

Fluorescence intensities of three fluorescence EEM components $(\mathrm{C} 1, \mathrm{C} 2$, and $\mathrm{C} 3)$ measured for the initial samples prior to the incubation exhibited downstream increases with the highest values at the urban tributaries (Fig. 3; Table S3a). Ratios among the three FDOM components, i.e., $\mathrm{C} 2 / \mathrm{C} 1, \mathrm{C} 3 / \mathrm{C} 1$, and $\mathrm{C} 3 / \mathrm{C} 2$, tended to be higher at the downstream and urban tributary sites compared to the up- and midstream sites. HIX was distinctly higher at the upstream sites and remained relatively small from the midstream to tributary sites, whereas FI and BIX increased gradually from the upstream sites toward the urban tributaries. Regression analyses revealed significant positive relationships between BDOC and many measured variables including $p \mathrm{CO}_{2}$, DOC, $a_{254}, a_{350}, \mathrm{C} 1, \mathrm{C} 2, \mathrm{C} 3$, and $\mathrm{FI}$ (Fig. 4). Over the 7 day incubation, $\mathrm{C} 3$ and its ratios to $\mathrm{C} 1$ and $\mathrm{C} 2$ showed significant decreases at the downstream and tributary samples (Fig. S1a), whereas $a_{350}, \mathrm{SUVA}_{254}$, and $S_{\mathrm{R}}$ increased significantly at the downstream samples (Fig. S1b). Fluorescence EEMs measured for the initial water samples exhibited pronounced downstream changes in the shape and intensity of major FDOM components, including the dominance of $\mathrm{C} 1$ at the upstream sites and $\mathrm{C} 3$ at the downstream sites and urban tributaries (Fig. S2). The differential EEMs obtained as the differences between the initial and final EEMs of the incubated samples showed site-specific contrasting patters of DOM consumption (i.e., reduction in fluorescence intensity during the incubation; indicated by blue color on Fig. S2) around the region designated as C3 and DOM production (i.e., increase in fluorescence intensity during the incubation; indicated by red color on Fig. S2) around C1 and C2 (Fig. S2). The differential EEMs of the forested headwater stream (Up 1) showed very little consumption or production compared to those for Up 2 and Up 3. While the differential EEMs of Mid 2 and Mid 3 were more pronounced in the production of new fluorescent components, all downstream samples revealed a predominant consumption to a greater extent than the upstream and midstream samples. The samples of Urban 1 also showed a predominance of consumption, but the two other urban tributaries displayed both consumption and production of DOM components. 
Biogeosciences Discuss., doi:10.5194/bg-2017-93, 2017

Manuscript under review for journal Biogeosciences

Discussion started: 22 March 2017

(c) Author(s) 2017. CC-BY 3.0 License.

$0.46 \mathrm{mg} \mathrm{L}^{-1}$ at the urban tributary, with differences between the samples largely corresponding to the initial DOC concentrations (Fig. 5a). The BDOC concentrations of the mixture samples were similar to the expected average value of the samples incubated in isolation. However, the 5 day \%BDOC values of all samples converged toward $10 \%$, with very small variations among the samples, after having passed a transition period between 24 and $72 \mathrm{~h}$, when the mainstem samples showed the highest values (Fig. 5b). The dissolved $\mathrm{CO}_{2}$ concentration was higher in the tributary sample than in the mainstem sample throughout the incubation (Fig. 5c). The dissolved $\mathrm{CO}_{2}$ concentration in the mixture sample exceeded the conservative mixing average calculated from the $\mathrm{CO}_{2}$ measurements of the two separate samples after the second day of incubation. Moreover, the cumulative $\mathrm{CO}_{2}$ production in the mixture sample, which was calculated as the cumulative increase in dissolved $\mathrm{CO}_{2}$ per unit water volume $\left(\mathrm{mg} \mathrm{C} \mathrm{L}^{-1}\right)$, exceeded the rates found in the mainstem and tributary samples from the second day, with the average production rate higher than the conservative mixing average by $60 \%$ (Fig. $5 \mathrm{~d}$ ).

The fluorescence EEMs of all initial samples prior to the incubation exhibited a predominance of the protein-like fluorescence peak around C3 (Fig. 6), contrasting with the EEM of the headwater stream sample dominated by the strong humic-like fluorescence peaks around C1 (Fig. S2). The fluorescence intensity of C3 was much higher in the tributary and mixture samples than in the mainstem samples (Fig. 6). The differential EEMs obtained as the differences between the initial and final EEMs for each incubation interval indicated a persistent consumption of protein-like components in the mainstem samples throughout the entire incubation period, as illustrated by blue color on the EEM indicating decreases in fluorescence intensity (Fig. 6). On the other hand, the production of new DOM components initially dominated the differential EEMs of the tributary samples, followed by the consumption of the newly produced components during the period from the first to the third day. The mixture samples showed more complex patterns with the consumption of protein-like components dominating during the first hour and a later phase from the first to the third day. Other optical properties of DOM also suggested a clear linkage between the consumption of protein-like components and DOM biodegradation (Fig. S3; Table S4). Although fluorescence intensities of $\mathrm{C} 3$ and the other components were in the descending order of the tributary, mixture, and mainstem samples, the disproportionately large ratios among three fluorescent components and other fluorescence indices 
Biogeosciences Discuss., doi:10.5194/bg-2017-93, 2017

Manuscript under review for journal Biogeosciences

Discussion started: 22 March 2017

(c) Author(s) 2017. CC-BY 3.0 License.

Krevelen diagrams at both sites and wide (Fig. 7). When the results of the FT-ICR-MS analyses before and after the incubation were compared, the molecular formulas whose peak intensities increased or decreased during the incubation indicate the relative production or consumption of the corresponding DOM components, respectively, compared to the initial intensities. Consistent with the patterns observed for the differential EEMs (Fig. 6), the comparison of the pre- and postincubation mainstem samples revealed more consumed organic molecules (3984 molecules) than the newly produced molecules (771 molecules). These patterns did not change when van Krevelen diagrams were produced with molecular formulas that showed 2-fold changes in peak intensity: 2303 consumed molecular formulas exceeding 601 produced molecular formulas (Fig. S4). In contrast, the tributary samples exhibited more production (2789 molecules) than consumption (1479 molecules) (Fig. 7). The production and consumption of molecular formulas were observed across the major molecular series including CHO, CHOP, CHOS, CHON, and CHONSP. At both sites the DOM composition was characterized by diverse molecular formulas enriched in heteroatoms $(\mathrm{N}, \mathrm{S}$, and $\mathrm{P})$. Although no consistent pattern was evident for each of the major molecular series, the pronounced consumption in the mainstem sample was associated with the $\mathrm{CHO}$ and P-containing molecular formulas compared to the rather diffuse consumption pattern of the tributary sample.

\section{Discussion}

\subsection{Longitudinal changes in optical properties and biodegradability of DOM}

Downstream increases in BDOC and $p \mathrm{CO}_{2}$ along the Han River and its urban tributaries (Fig. 2) suggest that anthropogenic perturbations caused by water impoundment and pollution exert a strong influence on OM biodegradation in this highly modified river system. Deviations from the overall pattern of downstream increases in $\mathrm{BDOC}$ and $p \mathrm{CO}_{2}$, as observed at some up-, mid-, and downstream sites (Fig. 2), might be explained by combined effects of local differences in the predominant land use, proximate pollution sources, and increased water retention along the impounded river reaches (Guo et al., 2014; Hosen et al., 2014; Hur et al., 2014a). For example, the increase in BDOC from Up 1 to Up 2 can be attributed to the intensive agricultural land use in the drained watershed (Jung et al., 2015). Streams draining agricultural lands have been shown to contain more bioavailable DOM moieties compared to forested and other natural streams ( Bellmore et al., 2015; Petrone et al., 2011; Williams et al., 2010, 2016). The slightly higher BDOC concentrations $\left(0.19 \pm 0.05 \mathrm{mg} \mathrm{C}^{-1} \mathrm{~L}^{-1}\right)$ and \%BDOC $(12.7 \pm 2.1 \%)$ measured for the midstream reach than those for the upstream sites (Table S3a) might reflect 
Biogeosciences Discuss., doi:10.5194/bg-2017-93, 2017

Manuscript under review for journal Biogeosciences

Discussion started: 22 March 2017

(c) Author(s) 2017. CC-BY 3.0 License.

dams ( Hur et al., 2014a; Williams et al., 2010). Highly variable BDOC concentrations at the downstream sites indicate the complex interplay between OM inputs from the upstream reservoirs and urban tributaries, the increased water retention by the weirs installed at both ends of the downstream reach, and tidal influences from the estuary (Guo et al., 2014; Hosen et al., 2014). Although urban tributaries bring high loads of bioavailable DOM to the downstream river (Fig. 2; Table S3), localized pulses of $p \mathrm{CO}_{2}$ along the confluences of the major urban tributaries observed in our continuous underway measurements of $p \mathrm{CO}_{2}$ along the same reach suggested rapid physical mixing and biological transformations of $\mathrm{CO}_{2}$ and $\mathrm{OM}$ in a relatively short section of the downstream river (Yoon et al., 2016). This localized effect of tributary inputs might explain the unexpectedly low BDOC concentration at Down 1that is located downstream of the tributary Urban 2 (Fig. 2). Similar to the high spatial variability observed for BDOC, optical properties were also highly variable across the mainstem and urban tributaries (Fig. 3; Fig. S1). Many optical properties exhibited positive relationships with BDOC concentrations (Fig. 4), as observed in other studies (Hosen et al., 2014; Knapik et al., 2015; Petrone et al., 2011; Williams et al., 2010). However, SUVA 254 and HIX values were not correlated with BDOC concentrations. Very high values of SUVA 254 and HIX found at the upstream sites compared to the downstream sites suggest a large contribution of terrestrial DOM components at the upstream sites and decreasing levels of humification along the downstream reaches (Helms et al., 2008). However, it is also possible that microbial production of humic-like DOM components can increase $\mathrm{SUVA}_{254}$ (Weishaar et al., 2003), as indicated by the slightly higher values of $\mathrm{SUVA}_{254}$ and HIX at the urban tributaries than at the downstream sites. The positive correlations between FI and BDOC concentrations imply a dominant contribution of autochthonous components to DOM biodegradation, consistent with previous findings (Petrone et al., 2011; Williams et al., 2010). Although all three FDOM components were correlated with BDOC concentrations, the regression slopes were steeper in the descending order of C3, C2, and C1 (Fig. 4), implying a greater contribution of protein-like FDOM components to BDOC. The strongly positive relationship between BDOC concentrations and in situ $p \mathrm{CO}_{2}$ measurements suggests that high loads of labile DOM components of autochthonous and allochthonous origin, such as protein-like FDOM components, can substantially enhance

Spatial differences in the dominant FDOM components, i.e. C1 along the up- and midstream reaches vs. C3 along the downstream reach and urban tributaries (Fig. 3), illustrate a strong longitudinal alteration of DOM composition corresponding to the level of anthropogenic perturbation (Hosen et al., 2014). In addition to the downstream increase in protein-like fluorescence intensity, the increases in the ratios of $\mathrm{C} 3 / \mathrm{C} 1$ and $\mathrm{C} 3 / \mathrm{C} 2$ along the downstream reach highlight the 
Biogeosciences Discuss., doi:10.5194/bg-2017-93, 2017

Manuscript under review for journal Biogeosciences

Discussion started: 22 March 2017

(c) Author(s) 2017. CC-BY 3.0 License.

in FI in contrast to decreasing HIX also adds up to the downstream evolution of DOM quality, as often observed in other anthropogenically affected inland water systems (Hosen et al., 2014; Petrone et al., 2011; Williams et al., 2010, 2016). The higher BIX values in the downstream and urban tributary sites compared to the upstream sites can be explained by enhanced microbial activities in the urbanized reach. Other studies have also shown that DOM composition in the eutrophic urban river can be dominated by microbially produced components with characteristic blue-shifted fluorescence peaks (Lee et al., 2015; Parlanti et al., 2000; Williams et al., 2010, 2016).

The significant decreases in C3 peak intensity in the incubated downstream and urban tributary samples (Fig. S1a), along with pronounced microbial humic-like peaks on the fluorescence EEMs (Fig. S2), suggest that the consumption of labile DOM components might concur with the production of autochthonous DOM components. In addition, the decrease in the ratio of $\mathrm{C}$ : $\mathrm{C} 1$ and $\mathrm{C} 3: \mathrm{C} 2$ (Fig. S1a) indicates a preferential consumption of protein-like components. The 7 day incubation with and without particulates did not show significant differences in BDOC concentration and other optical properties at all sites, probably due to the relatively low concentrations of TSS in the water samples collected during the dry season (Table S3b). If the incubation were conducted with samples collected during high-flow periods that would have much higher TSS and POM concentrations, the contribution of particulates to BDOC might be more evident across the sites (Jung et al., 2015). Future research should encompass more diverse urban water systems including pollution sources such as WWTP effluents and seasonal variability in hydrologic conditions to better constrain the spatial and temporal patterns of DOM properties and biodegradation in anthropogenically modified river systems.

\subsection{Priming effects of urban tributary inputs on riverine biodegradation and $\mathrm{CO}_{2}$ production}

The unexpectedly high rate of cumulative $\mathrm{CO}_{2}$ production in the mixture sample exceeding the rates measured for the separate samples (Fig. 5d) supports our hypothesis that the mixing of the mainstem and urban tributary waters can enhance the biodegradation of "native" stable organic components in the presence of "external" labile materials, consistent with positive priming effects observed in various aquatic systems (Bianchi et al., 2015; Guenet et al., 2014; Hotchkiss et al., 2014; Kuehn et al., 2014). Inputs of external labile organic materials can provide heterotrophic microbial decomposers with energy-rich compounds, promoting the overall metabolic capacity through increases in microbial cells and/or the activity of enzymes involved in degrading recalcitrant components (Guenet et al., 2014; Hotchkiss et al., 2014; Kuehn et al., 2014). 
Biogeosciences Discuss., doi:10.5194/bg-2017-93, 2017

Manuscript under review for journal Biogeosciences

Discussion started: 22 March 2017

(c) Author(s) 2017. CC-BY 3.0 License.

Although labile organic moieties in algal and macrophyte exudates have been shown to prime the biodegradation of allochthonous organic materials in artificially concocted water samples, few studies have examined how microbial organisms would respond to the addition of labile compounds to the existing organic materials in real river waters with different levels of OM lability (Hotchkiss et al., 2014; Kuehn et al., 2014). Identifying sources and target components of priming is very challenging because our experimental design did not include model compounds with distinct chemical signatures such as $\mathrm{C}$ isotopes that could be used to track priming-induced changes in optical properties of different DOM components (Bianchi et al., 2015). However, the increased rate of $\mathrm{CO}_{2}$ production and more complex changes in the fluorescence EEMs of the mixture samples provided indirect lines of evidence for the enhanced degradation of stable OM moieties in the presence of more labile components that might have been produced in the upstream reservoirs or during the transport along the downstream reach receiving polluted urban steams.

More complex patterns of the EEM peaks observed for the mixture samples than those for the separate samples (Fig. 6) provide a visual manifestation of priming-enhanced alterations of DOM composition. The pronounced enhancement ("production") and subsequent decrease ("consumption") in the intensity of fluorescence peaks around C2 over the first three days indicate a significant contribution of microbially produced or converted materials to the overall microbial processing of the OM pool becoming increasingly depleted of labile components. The prevailing consumption of labile DOM components in the mainstem samples, as indicated by the differential EEMs dominated by the reduction of the protein-like fluorescence (C3), agrees with the decreased peak intensities of as many as 3984 molecular formulas identified by the FT-ICR-MS analysis (Fig. 7). The alternation of the strong enhancement and reduction of two humic-like FDOM components ( $\mathrm{C} 1$ and $\mathrm{C} 2)$ shown on the tributary differential EEMs, combined with the produced molecular formulas (2789 peaks) exceeding the consumed molecular formulas (1479 peaks) on the van Krevelen diagrams, supports the idea of active processing of the tributary DOM pool, which might have been accelerated further following the addition of more labile components contained in the mainstem to the tributary water.

The van Krevelen diagrams of both mainstem and tributary samples exhibited a large number of organic molecules with molecular formula distributions similar to those found for anthropogenically impacted rivers (Arnold et al., 2014; Gonsior et al., 2011; Mesfioui et al., 2012; Wagner et al., 2015). The observed complex patterns of molecular formula distribution are distinguished from the molecular formulas identified for unaffected headwater streams, which are usually dominated by CHO molecular series and lignin-like components characterized by an $\mathrm{O} / \mathrm{C}$ molar ratio of $0.25-0.5$ and an $\mathrm{H} / \mathrm{C}$ molar ratio 
Biogeosciences Discuss., doi:10.5194/bg-2017-93, 2017

Manuscript under review for journal Biogeosciences

Discussion started: 22 March 2017

(c) Author(s) 2017. CC-BY 3.0 License.

of 1-1.5 (Jaffé et al., 2012; Kim et al., 2006; Lu et al., 2015). It has been shown that the composition of DOM in natural waters is dominated by $\mathrm{C}, \mathrm{H}, \mathrm{O}$, and $\mathrm{N}$, with minor contributions of $\mathrm{P}$ and $\mathrm{S}$ (Koch et al., 2007). While comparing molecular signatures identified for ten global rivers, Wagner et al. (2015) found the molecular formulas unique to anthropogenically impacted rivers, including highly diverse heteroatomic formulas enriched in $\mathrm{N}$ and $\mathrm{S}$, which have also been identified in wastewater effluents and septic waters (Arnold et al., 2014; Gonsior et al., 2011; Mesfioui et al., 2012). Compared to the usual composition of molecular series identified for headwater streams (Lu et al., 2015) and large rivers with low levels of pollution (Wagner et al., 2015), the high enrichment of $\mathrm{N}$ - and S-containing formulas in both the mainstem and tributary samples (Figs. 7, S4) points to the strong influence of anthropogenic DOM across the downstream reaches and urban tributaries. The high enrichment of S-containing formulas in WWTP effluents has been attributed to the presence of surfactants and their co-products and biodegraded metabolites (Gonsior et al., 2011). Incubation-induced decreases of CHOP and CHONSP formulas in the range of the $\mathrm{O} / \mathrm{C}$ molar ratio of $0-0.2$ and an $\mathrm{H} / \mathrm{C}$ molar ratio of $0.5-1$, which has been associated with condensed hydrocarbons, were particularly distinct on the "consumption" diagram of the mainstem sample, indicating a preferential consumption of labile, P-containing components that might have been transferred from the upstream reservoir and/or produced in the slowly moving water along the mainstem channel. Other studies have also shown that the van Krevelen diagrams of the DOM dominated by materials produced in lakes or impounded rivers are characterized by condensed hydrocarbon regions and higher proportions of heteroatomic formulas containing N, S, and P (Minor et al., 2012; Wagner et al., 2015).

Previous incubation studies employing FT-ICR-MS showed a biodegradation-induced shift in mass distribution toward a dominance of lower-mass molecules (Kim et al., 2006) and a rather selective consumption of bioreactive molecules associated with protein- and lipid-like regions of the van Krevelen diagrams (Lu et al., 2015). Unlike the preferential utilization of higher molecular weight fraction observed in upstream streams (Kim et al., 2006), a wide range of produced or microbial processing of organic molecules in both mainstem and tributary samples. However, the greater number of newly produced molecules relative to the small number of consumed molecules in the tributary samples, combined with mixingenhanced changes in $\mathrm{CO}_{2}$ production and optical indices, suggests that organic materials in the urban tributary are already highly processed by microbial decomposers that might be limited by labile components, unlike the mainstem water that appears to contain more labile, autochthonous materials derived from the upstream impounded reach. 
Biogeosciences Discuss., doi:10.5194/bg-2017-93, 2017

Manuscript under review for journal Biogeosciences

Discussion started: 22 March 2017

(c) Author(s) 2017. CC-BY 3.0 License.

The prevailing OM consumption observed in the mainstem samples is consistent with the fact that decreases in both fluorescence ratios $\mathrm{C} 3 / \mathrm{C} 1$ and $\mathrm{C} 3 / \mathrm{C} 2$ were steeper in the mainstem than in the tributary samples (Fig. S3). The preferential consumption of protein-like components relative to more recalcitrant components implies the relative abundance of bioreactive molecules in the mainstem samples receiving high inputs of labile autochthonous DOM produced in the upstream reservoirs, as often observed in other impounded rivers (Hur et al., 2014a; Stanley et al., 2011). In the case of the tributary DOM dynamics, the production of DOM components was pronounced during the initial phase, indicating rapid production and/or transformation from depleting bioavailable DOM components including the labile fraction of POM. Another possible explanation for the high OM production in the tributary sample might be substrate-specific high efficiency of microbial assimilation of highly processed DOM components in the tributary (Ward et al., 2013). Eutrophic urban streams and rivers receiving untreated or treated wastewaters have been found to contain characteristic microbial communities, which are often less diverse but highly efficient in utilizing food resources available in the urban water environment than in less affected waters (Shanks et al., 2013; Winter et al., 2007). The diversification of C sources in the mixture samples was likely to prime the degradation of stable organic components in both source waters (Kuehn et al., 2014). The processing of $\mathrm{OM}$ in the mixture samples might have been accelerated by the addition of a microbial community that is efficient in assimilating organic compounds available in the urban tributary to the mainstem sample enriched in labile DOM components, as illustrated by complex patterns of EEM peaks switching toward a pattern dominated by consumption (Fig. 6) that concurred with the increasing rate of $\mathrm{CO}_{2}$ production (Fig. 5). Complementing the conventional approach based on BDOC determination with continuous measurements of dissolved $\mathrm{CO}_{2}$ in unfiltered water samples provided data supporting the contribution of labile particulate components to DOM 
Biogeosciences Discuss., doi:10.5194/bg-2017-93, 2017

Manuscript under review for journal Biogeosciences

Discussion started: 22 March 2017

(c) Author(s) 2017. CC-BY 3.0 License.

(c) (i)

these components was often ascribed to enhanced microbial processing of OM in eutrophic waters (Jung et al., 2015; Osburn et al., 2012). Quantifying the contribution of the labile fraction of POM to DOM biodegradation would be very difficult due to the continuous conversion between POM and DOM during downstream transport (del Giorgio and Pace, 2008; Jung et al., 2015).

\section{Conclusions}

Complex longitudinal patterns of $p \mathrm{CO}_{2}$ and the optical properties and biodegradability of DOM observed in the Han River suggest that the traditional view of gradual downstream changes in riverine OM composition based on the river continuum concept (Vannote et al., 1980) may be invalid in explaining discontinuities in DOM properties and biodegradability across the impounded or polluted river reaches of highly modified river systems. Although the limited sampling frequency and spatial coverage did not allow us to examine local land use effects at high spatial and temporal resolutions, the field survey combining in situ $\mathrm{pCO}_{2}$ measurements and laboratory incubations revealed two pronounced longitudinal patterns reflecting the dominant anthropogenic perturbations to the studied river system: impoundment effects along the midstream reach and water pollution effects along the downstream reach. Increased primary production in the impounded reach, as indicated by lower $p \mathrm{CO}_{2}$ values as compared with the upstream reach, can enhance the biodegradability of DOM by providing labile DOM components of autochthonous origin. The downstream reach receiving the dam discharge enriched in autochthonous organic materials and urban tributaries delivering anthropogenic materials discharged from WWTPs exhibited substantially elevated levels of $p \mathrm{CO}_{2}$ and DOM optical indices. However, large spatial variabilities in $p \mathrm{CO}_{2}$ and $\mathrm{BDOC}$ across the downstream sites and urban tributaries suggest that microbial OM processing in the mixed waters from the upstream reservoir and urban tributaries can occur very rapidly along short river sections receiving urban tributaries and at paces that have not been observed in natural river systems.

Unlike the recent studies of priming effects on DOM biodegradation that have focused on the stimulation of the biodegradation of the recalcitrant terrestrial DOM by labile autochthonous components (Bianchi et al., 2015; Catalan et al., 2015; Hotchkiss et al., 2014; Kuehn et al., 2014), the mixing-induced changes in $\mathrm{CO}_{2}$ production and DOM optical properties in the second incubation experiment, which were distinctively larger than the values measured separately in the urban tributary and the river water receiving dam discharge, underscore the importance of microbial processing in transforming OM components of both autochthonous and anthropogenic origin and subsequently inducing a priming effect 
Biogeosciences Discuss., doi:10.5194/bg-2017-93, 2017

Manuscript under review for journal Biogeosciences

Discussion started: 22 March 2017

(c) Author(s) 2017. CC-BY 3.0 License.

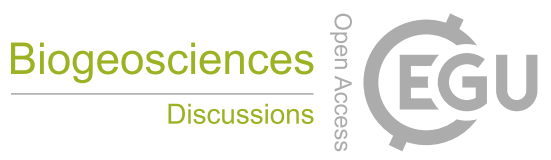

(c) (i)

on the biodegradation of the bulk riverine OM in the eutrophic streams and rivers draining highly modified river systems. The larger rate of $\mathrm{CO}_{2}$ production than the BDOC measured in the unfiltered mixture sample pointed to the potential contribution of POM, raising a possibility that the conventional experimental design excluding the particulate component might significantly underestimate priming effects on the biodegradation of the actual riverine OM that includes both DOM and POM. Considering that under real field conditions photodegradation can accelerate the biodegradation of physically degraded OM components, priming effects may be stronger in the field than in the dark incubator. Therefore, future research should involve in situ measurements of $\mathrm{OM}$ biodegradation and $\mathrm{CO}_{2}$ production by conducting incubation experiments under both dark and light conditions. If isotopically distinct or labelled materials are used in field incubation experiments, the results can also be used to track the sources of the released $\mathrm{CO}_{2}$ and the pathways of OM conversion. To better assess the role of anthropogenically impacted rivers in the regional and global carbon budgets, more field-based studies of site-specific anthropogenic influences should be conducted in a wide range of systems including urban, agricultural, and impounded rivers.

\section{Data availability}

Data are available and can be requested from the corresponding author (jhp@ewha.ac.kr).

\section{Supporting information}

Materials and Methods described in detail, supplementary tables (Table S1; Table S2; Table S3a; Table S3b; Table S4a; Table S4b) and supplementary figures (Fig. S1a; Fig. S1b; Fig. S2; Fig. S3).

\section{Author contribution}

All authors contributed to data acquisition, the discussion of the results, and manuscript preparation. The manuscript was written by concerted efforts of J.-H. Park, H. B. Oh, and M.S. Begum.

\section{Competing interests}

The authors declare that they have no conflict of interest.

\section{Acknowledgments}

This work was supported by the National Research Foundation of Korea funded by the Korean Government (2014R1A2A2A01006577). We thank Dr. Tae Kyung Yoon and Borami Park for their assistance with sampling and analysis. 
Biogeosciences Discuss., doi:10.5194/bg-2017-93, 2017

Manuscript under review for journal Biogeosciences

Discussion started: 22 March 2017

(c) Author(s) 2017. CC-BY 3.0 License.

Abril, G., Nogueira, M., Etcheber, H., Cabeçadas, G., Lemaire, E. and Brogueira, M.: Behaviour of organic carbon in nine contrasting European estuaries, Estuar. Coast. Shelf Sci., 54, 241-262, doi:10.1006/ecss.2001.0844, 2002.

Arnold, W. A., Longnecker, K., Kroeger, K. D. and Kujawinski, E. B, Molecular signature of organic nitrogen in septicimpacted groundwater, Environ. Sci. Process. Impacts, 16 (10), 2400-2407, 2014. Riverine coupling of biogeochemical cycles between land, oceans, and atmosphere, Front. Ecol. Environ., 9(1), 53-60, doi:10.1890/100014, 2011.

Baker, A.: Fluorescence excitation-emission matrix characterization of some sewage-impacted rivers, Environ. Sci. Technol., 35(5), 948-953, doi:10.1021/es000177t, 2001.

Bastviken, D., Tranvik, L. J., Downing, J. A., Crill, P. M., and Enrich-Prast, A.: Freshwater methane emissions offset the continental carbon sink, Science, 331, 50, 2011.

Bellmore, R., Harrison, J., Needoba, J., Brooks, E. and Keller, C.: Hydrologic control of dissolved organic matter concentration and quality in a semiarid artificially drained agricultural catchment, Water Resour. Res., 51, 8146-8164,

Bianchi, T. S.: The role of terrestrially derived organic carbon in the coastal ocean: A changing paradigm and the priming effect, Proc. Natl. Acad. Sci., 108(49), 19473-19481, doi:10.1073/pnas.1017982108, 2011.

Bianchi, T. S., Thornton, D. C. O., Yvon-lewis, S. A., King, G. M., Eglinton, T. I., Shields, M. R., Ward, N. D. and Curtis, J.: 2015GL064765, 2015.

Casas-Ruiz, J. P., Tittel, J., von Schiller, D., Catalán, N., Obrador, B., Gómez-Gener, L., Zwirnmann, E., Sabater, S. and Marcé, R.: Drought-induced discontinuities in the source and degradation of dissolved organic matter in a Mediterranean river, Biogeochemistry, 127, 125-139, doi:10.1007/s10533-015-0173-5, 2016.

Catalan, N., Kellerman, A. M., Peter, H., Carmona, F. and Tranvik, L. J.: Absence of a priming effect on dissolved organic carbon degradation in lake water, Limnol. Oceanogr., 60, 159-168, doi:10.1002/lno.10016, 2015.

Chang, H.: Spatial analysis of water quality trends in the Han River basin, South Korea, Water Res., 42, 3285-3304, doi:10.1016/j.watres.2008.04.006, 2008 . 
Biogeosciences Discuss., doi:10.5194/bg-2017-93, 2017

Manuscript under review for journal Biogeosciences

Discussion started: 22 March 2017

(c) Author(s) 2017. CC-BY 3.0 License.

Cole, J. J., Prairie, Y. T., Caraco, N. F., McDowell, W. H., Tranvik, L. J., Striegl, R. G., Duarte, C. M., Kortelainen, P., Downing, J. A., Middelburg, J. J. and Melack, J.: Plumbing the global carbon cycle: Integrating inland waters into the terrestrial carbon budget, Ecosystems, 10(1), 171-184, doi:10.1007/s10021-006-9013-8, 2007.

Dittmar, T., Koch, B., Hertkorn, N. and Kattner, G.: A simple and efficient method for the solid-phase extraction of dissolved organic matter (SPE-DOM) from seawater, Limnol. Ocean. Methods, 6, 230-235, doi:10.4319/lom.2008.6.230, 2008.

Fellman, J. B., Hood, E. and Spencer, R. G. M.: Fluorescence spectroscopy opens new windows into dissolved organic matter dynamics in freshwater ecosystems: A review, Limnol. Oceanogr., 55(6), 2452-2462, doi:10.4319/lo.2010.55.6.2452, 2010 .

del Giorgio, P. a. and Pace, M. L.: Relative independence of dissolved organic carbon transport and processing in a large temperate river: The Hudson River as both pipe and reactor, Limnol. Oceanogr., 53(1), 185-197, doi:10.4319/lo.2008.53.1.0185, 2008.

Gonsior, M., Zwartjes, M., Cooper, W. J., Song, W., Ishida, K.P., Tseng, L. Y., Jeung, M. K., Rosso, D.; Hertkorn, N., and Schmitt-Kopplin, P.: Molecular characterization of effluent organic matter identified by ultrahigh resolution mass spectrometry, Water Res., 45, 2943-2953, 2011.

Guenet, B., Danger, M., Harrault, L., Allard, B., Jauset-Alcala, M., Bardoux, G., Benest, D., Abbadie, L. and Lacroix, G.: Fast mineralization of land-born $\mathrm{C}$ in inland waters: First experimental evidences of aquatic priming effect, Hydrobiologia, 721(1), 35-44, doi:10.1007/s10750-013-1635-1, 2014.

Guo, W., Yang, L., Zhai, W., Chen, W., Osburn, C. L., Huang, X. and Li, Y.: Runoff-mediated seasonal oscillation in the dynamics of dissolved organic matter in different branches of a large bifurcated estuary - The Changjiang Estuary, J. Geophys. Res. Biogeosciences, 119(5), 776-793, doi:10.1002/2013JG002540, 2014.

Helms, J. R., Stubbins, A., Ritchie, J. D., Minor, E. C., Kieber, D. J. and Mopper, K.: Absorption spectral slopes and slope ratios as indicators of molecular weight, source, and photobleaching of chromophoric dissolved organic matter, Limonology Oceanogr., 53(3), 955-969, doi:10.4319/lo.2008.53.3.0955, 2008. 
Biogeosciences Discuss., doi:10.5194/bg-2017-93, 2017

Manuscript under review for journal Biogeosciences

Discussion started: 22 March 2017

(c) Author(s) 2017. CC-BY 3.0 License. doi:10.1002/2013JG002599, 2014.

Huguet, A., Vacher, L., Relexans, S., Saubusse, S., Froidefond, J. M. and Parlanti, E.: Properties of fluorescent dissolved organic matter in the Gironde Estuary, Org. Geochem., 40(6), 706-719, doi:10.1016/j.orggeochem.2009.03.002, 2009.

Hur, J., Lee, B.-M., Lee, S. and Shin, J.-K.: Characterization of chromophoric dissolved organic matter and trihalomethane formation potential in a recently constructed reservoir and the surrounding areas - Impoundment effects, J. Hydrol., 515, 71-80, doi:10.1016/j.jhydrol.2014.04.035, 2014a.

Hur, J., Nguyen, H. V. M. and Lee, B. M.: Influence of upstream land use on dissolved organic matter and trihalomethane formation potential in watersheds for two different seasons, Environ. Sci. Pollut. Res., 21(12), 7489-7500, doi:10.1007/s11356-014-2667-4, 2014b.

Hutyra, L. R., Duren, R., Gurney, K. R., Grimm, N., Kort, E. a., Larson, E. and Shrestha, G.: Urbanization and the carbon cycle: Current capabilities and research outlook from the natural sciences perspective, Earth's Futur., 2(10), 473-495, doi:10.1002/2014EF000255, 2014.

Jaffé, R., Yamashita, Y., Maie, N., Cooper, W. T., Dittmar, T., Dodds, W. K., Jones, J. B., Myoshi, T., Ortiz-Zayas, J. R., Podgorski, D. C. and Watanabe, A.: Dissolved organic matter in headwater streams: Compositional variability across climatic regions of North America, Geochim. Cosmochim. Acta, 94, 95-108, doi:10.1016/j.gca.2012.06.031, 2012. dissolved carbon dioxide in freshwater aquatic systems - Method and applications, Ecohydrology, 3, 68-78, doi:10.1002/eco.95, 2010.

Jung, B. J., Jeanneau, L., Alewell, C., Kim, B. and Park, J. H.: Downstream alteration of the composition and 99, doi:10.1007/s10533-014-0032-9, 2015.

Jung, S. W., Kwon, O. Y., Yun, S. M., Joo, H. M., Kang, J.-H. and Lee, J. H.: Impacts of dam discharge on river environments and phytoplankton communities in a regulated river system, the lower Han River of South Korea, J. Ecol. 
Biogeosciences Discuss., doi:10.5194/bg-2017-93, 2017

Manuscript under review for journal Biogeosciences

Discussion started: 22 March 2017

(c) Author(s) 2017. CC-BY 3.0 License.

Kaushal, S. S., McDowell, W. H. and Wollheim, W. M.: Tracking evolution of urban biogeochemical cycles: past, present, and future, Biogeochemistry, 121(1), 1-21, doi:10.1007/s10533-014-0014-y, 2014.

Kim, S., Kaplan, L. A. and Hatcher, P. G.: Biodegradable dissolved organic matter in a temperate and a tropical stream determined from ultra-high resolution mass spectrometry, Limnol. Oceanogr., 51(2), 1054-1063, doi:10.4319/lo.2006.51.2.1054, 2006.

Knapik, H. G., Fernandes, C. V. S., de Azevedo, J. C. R., dos Santos, M. M., Dall'Agnol, P. and Fontane, D. G.: Biodegradability of anthropogenic organic matter in polluted rivers using fluorescence, UV, and BDOC measurements, Environ. Monit. Assess., 187(3), 104, doi:10.1007/s10661-015-4266-3, 2015.

Koch, B. P., Dittmar, T., Witt, M. and Kattner, G.: Fundamentals of molecular formula assignment to ultrahigh resolution mass data of natural organic matter, Anal. Chem., 79(4), 1758-1763, doi:10.1021/AC061949S, 2007.

Kuehn, K. A., Francoeur, S. N., Findlay, R. H. and Neely, R. K.: Priming in the microbial landscape: Periphytic algal stimulation of litter-associated microbial decomposers, Ecology, 95(3), 749-762, doi:10.1890/13-0430.1, 2014.

Kuzyakov, Y., Friedel, J. K. and Stahr, K.: Review of mechanisms and quantification of priming effects, Soil Biol. Biochem., 32, 1485-1498, doi:10.1016/S0038-0717(00)00084-5, 2000.

Lee, S. T., Yang, B., Kim, J.-Y., Park, J.-H. and Moon, M. H.: Combining asymmetrical flow field-flow fractionation with on- and off-line fluorescence detection to examine biodegradation of riverine dissolved and particulate organic matter, J. Chromatogr. A, 1409, 218-225, doi:10.1016/j.chroma.2015.07.074, 2015. characterize dissolved organic matter in headwater streams draining forest-dominated and pasture-dominated watersheds, PLoS One, 10(12), 1-21, doi:10.1371/journal.pone.0145639, 2015.

McElmurry, S. P., Long, D. T. and Voice, T. C.: Stormwater dissolved organic matter: influence of land cover and environmental factors, Environ. Sci. Technol., 48(1), 45-53, doi:10.1021/es402664t, 2014. Oceanogr., 46(1), 38-48, doi:10.4319/lo.2001.46.1.0038, 2001. 1993. 
Biogeosciences Discuss., doi:10.5194/bg-2017-93, 2017

Manuscript under review for journal Biogeosciences

Discussion started: 22 March 2017

(c) Author(s) 2017. CC-BY 3.0 License.

Ohno, T.: Fluorescence inner-filtering correction for determining the humification index of dissolved organic matter, Environ. particulate organic matter quality in a river-dominated estuary, Environ. Sci. Technol., 46(16), 8628-8636, doi:10.1021/es3007723, 2012.

Parlanti, E., Worz, K., Geoffroy, L. and Lamotte, M.: Dissolved organic matter fluorescence spectroscopy as a tool to estimate biological activity in a coastal zone submitted to anthropogenic inputs, Org. Geochem., 31, 1765-1781, doi:10.1016/S0146-6380(00)00124-8, 2000.

Parr, T. B., Cronan, C. S., Ohno, T., Findlay, S. E. G., Smith, S. M. C. and Simon, K. S.: Urbanization changes the composition and bioavailability of dissolved organic matter in headwater streams, Limnol. Oceanogr., 60(3), 885-900, doi:10.1002/lno.10060, 2015. Computing: Vienna, Austria, available at https://www.r-project.org: last access 27 February 2017. Humborg, C., Kortelainen, P., Durr, H., Meybeck, M., Ciais, P. and Guth, P.: Global carbon dioxide emissions from inland waters, Nature, 503(7476), 355-359, doi:10.1038/nature12760, 2013. 
Biogeosciences Discuss., doi:10.5194/bg-2017-93, 2017

Manuscript under review for journal Biogeosciences

Discussion started: 22 March 2017

(c) Author(s) 2017. CC-BY 3.0 License.

Royer, T. V. and David, M. B.: Export of dissolved organic carbon from agricultural streams in Illinois, USA, Aquat. Sci., 67(4), 465-471, doi:10.1007/s00027-005-0781-6, 2005.

Servais, P., Billen, G. and Hascoet, M.-C.: Determination of the biodegradable fraction of dissolved organic matter in waters, Water Res., 21(4), 445-450, doi:10.1016/0043-1354(87)90192-8, 1987.

Shanks, O. C., Newton, R. J., Kelty, C. A., Huse, S. M., Sogin, M. L. and McLellan, S. L.: Comparison of the microbial community structures of untreated wastewaters from different geographic locales, Appl. Environ. Microbiol., 79(9), 29062913, doi:10.1128/AEM.03448-12, 2013.

Shi, J., Cui, H., Jia, L., Qiu, L., Zhao, Y., Wei, Z., Wu, J. and Wen, X.: Bioavailability of riverine dissolved organic carbon and nitrogen in the Heilongjiang watershed of northeastern China, Environ. Monit. Assess., 188(2), 113, doi:10.1007/s10661-016-5120-y, 2016.

Spencer, R. G. M., Butler, K. D. and Aiken, G. R.: Dissolved organic carbon and chromophoric dissolved organic matter properties of rivers in the USA, J. Geophys. Res. Biogeosciences, 117(3), G03001, doi:10.1029/2011JG001928, 2012. Stanley, E. H., Powers, S. M., Lottig, N. R., Buffam, I. and Crawford, J. T.: Contemporary changes in dissolved organic carbon (DOC) in human-dominated rivers: Is there a role for DOC management?, Freshw. Biol., 57, 26-42, doi:10.1111/j.1365-2427.2011.02613.x, 2011.

Stubbins, A., Spencer, R.G.M., Chen, H., Hatcher, P.G., Mopper, K., Hernes, P.J., Mwamba, V.L., Mangangu, A. M., Wabakanghanzi, J.N., Six, J.: Illuminated darkness: molecular signature of Congo river dissolved organic matter and its photochemical alteration as revealed by ultrahigh precision mass spectrometry, Limnol. Oceanogr., 55(4), 1467-1477, DOI: $10.4319 / 10.2010 .55 .4 .1467,2010$. Aquat. Sci., 37, 130-137, 1980.

Wagner, S., Riedel, T., Niggemann, J., Vähätalo, A. V., Dittmar, T. and Jaffé, R.: Linking the molecular signature of heteroatomic dissolved organic matter to watershed characteristics in world rivers, Environ. Sci. Technol., 49(23), 1379813806, doi:10.1021/acs.est.5b00525, 2015. 
Biogeosciences Discuss., doi:10.5194/bg-2017-93, 2017

Manuscript under review for journal Biogeosciences

Discussion started: 22 March 2017

(c) Author(s) 2017. CC-BY 3.0 License.

Water Resources Management Information System (WAMIS): http://www.wamis.go.kr/ENG/WKB_LCSTBB_LST.aspx, last access: 27 February 2017.

Wehrli, B.: Conduits of the carbon cycle, Nature, 503(21), 346-347, doi:10.1038/503346a, 2013.

Weishaar, J. L., Aiken, G. R., Bergamaschi, B. A., Fram, M. S., Fujii, R. and Mopper, K.: Evaluation of specific ultra-violet absorbance as an indicator of the chemical composition and reactivity of dissolved organic carbon, Environ. Sci. Technol., 37(20), 4702-4708, doi:10.1021/es030360x, 2003.

Wickland, K. P., Aiken, G. R., Butler, K., Dornblaser, M. M., Spencer, R. G. M. and Striegl, R. G.: Biodegradability of dissolved organic carbon in the Yukon River and its tributaries: Seasonality and importance of inorganic nitrogen, Global Biogeochem. Cycles, 26(3), GB0E03, doi:10.1029/2012GB004342, 2012.

Williams, C. J., Yamashita, Y., Wilson, H. F., Jaffe, R., Xenopoulos, M. a., Jaffé, R. and Xenopoulos, M. a.: Unraveling the role of land use and microbial activity in shaping dissolved organic matter characteristics in stream ecosystems, Limnol. Oceanogr., 55(3), 1159-1171, doi:10.4319/lo.2010.55.3.1159, 2010.

Williams, C. J., Frost, P. C., Morales-Williams, A. M., Larson, J. H., Richardson, W. B., Chiandet, A. S. and Xenopoulos, M. A.: Human activities cause distinct dissolved organic matter composition across freshwater ecosystems, Glob. Chang. Biol., 22(2), 613-626, doi:10.1111/gcb.13094, 2016.

Wilson, H. F. and Xenopoulos, M. a.: Effects of agricultural land use on the composition of fluvial dissolved organic matter, Nat. Geosci., 2(1), 37-41, doi:10.1038/ngeo391, 2009.

Winter, C., Hein, T., Kavka, G., Mach, R. L. and Farnleitner, A. H.: Longitudinal changes in the bacterial community composition of the Danube River: A whole-river approach, Appl. Environ. Microbiol., 73(2), 421-431, doi:10.1128/AEM.01849-06, 2007.

Yoon, T. K., Jin, H., Oh, N.-H. and Park, J.-H.: Technical note: Assessing gas equilibration systems for continuous $p \mathrm{CO}_{2}$ measurements in inland waters, Biogeosciences, 13(13), 3915-3930, doi:10.5194/bg-13-3915-2016, 2016. and personal care products in the Han River (Seoul, South Korea), Sci. Total Environ., 408(3), 636-643, doi:10.1016/j.scitotenv.2009.10.049, 2010. 
Biogeosciences Discuss., doi:10.5194/bg-2017-93, 2017

Manuscript under review for journal Biogeosciences

Discussion started: 22 March 2017

(C) Author(s) 2017. CC-BY 3.0 License.

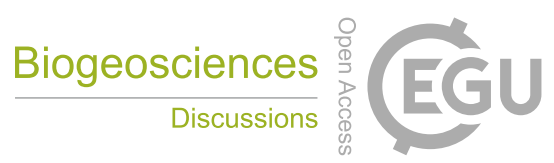

(c) (i)

695 sources of dissolved organic matter in soils subjected to drying, Chemosphere, 38(1), 45-50, doi:10.1016/S0045-

$696 \quad 6535(98) 00166-0,1999$.

697 
Biogeosciences Discuss., doi:10.5194/bg-2017-93, 2017

Manuscript under review for journal Biogeosciences

Discussion started: 22 March 2017

(c) Author(s) 2017. CC-BY 3.0 License.

(c) (i)

\section{Figure captions}

Fig. 1. Sampling locations in the Han River basin, South Korea. The locations of major dams along the midstream reach and waste water treatment plants (WWTPs) along the downstream reach are also indicated by different symbols. Note that a red triangle termed "mainstem" indicates the location of the mainstem sample used for the second incubation.

Fig. 2. Initial $p \mathrm{CO}_{2}$ levels measured in situ and BDOC concentrations measured with the filtered and unfiltered samples during 7 day laboratory incubation. BDOC concentrations represent the means of three replicate measurements $( \pm$ one standard deviation), whereas one spot measurement of $p \mathrm{CO}_{2}$ was conducted at each site except site Urban 3. Asterisks above the site name indicate significant $(P<0.05)$ differences in the BDOC concentration between the filtered and unfiltered samples.

Fig. 3. Spatial variation in DOM optical indices measured for the pre-incubation samples from up-, mid-, and downstream reaches and urban tributaries of the Han River. Error bars indicate a standard deviation of the measurements at three sites in each group. Significant differences among the up-, mid-, and downstream reaches and urban tributary sites are indicated by the different letters above the error bar.

Fig. 4. Relationships between $\mathrm{BDOC}$ and $p \mathrm{CO}_{2}$, DOC concentration, or optical indices. All significant regressions at $P<$ 0.05 except HIX and SUVA $_{25}$ are indicated by dotted lines through the plots.

Fig. 5. Short-term dynamics of $\mathrm{DOC}$ and $\mathrm{CO}_{2}$ during the 5 day incubation of unfiltered water samples including a mainstem and a tributary of the Han River and their mixture (1:1); (a) DOC concentrations $\left(\mathrm{mg} \mathrm{C} \mathrm{L}^{-1}\right)$ and cumulative BDOC concentrations ( $\mathrm{mg} \mathrm{C} \mathrm{L}^{-1}$ ); (b) DOC concentrations ( $\mathrm{m} \mathrm{C} \mathrm{L} \mathrm{L}^{-1}$ ) and \%BDOC relative to the initial DOC; (c) dissolved $\mathrm{CO}_{2}$ concentration $\left(\mathrm{mg} \mathrm{C} \mathrm{L}^{-1}\right)$; (d) cumulative production of $\mathrm{CO}_{2}\left(\mathrm{mg} \mathrm{C} \mathrm{L}^{-1}\right)$. The mainstem and tributary samples were collected from sites "mainstem" and "Urban 2" marked in Figure 1, respectively.

Fig. 6. Initial and differential fluorescence EEMs obtained at 0 h, 1 h, 1 day, 3 day, and 5 day during the 5 day incubation of unfiltered water samples; including a mainstem sample (first and second panels) and a tributary sample (third and fourth panels) of the Han River and their 1:1 mixture (fifth and sixth panels). Positive and negative values in differential EEMs indicate production and consumption of DOM components, respectively.

Fig. 7. Van Krevelen diagrams of identified molecular formulas showing changes in the peak intensity relative to the initial value during a 5 day incubation of unfiltered water samples from (a) a mainstem and (b) a tributary site of the Han River. Red and blue symbols represent molecular formulas that increased (termed "production") and decreased (termed 
Biogeosciences Discuss., doi:10.5194/bg-2017-93, 2017

Manuscript under review for journal Biogeosciences

Discussion started: 22 March 2017

(c) Author(s) 2017. CC-BY 3.0 License.

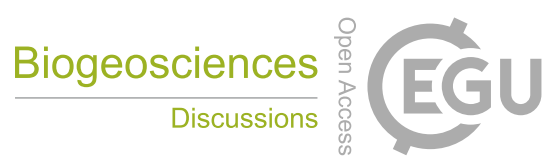

(c) (i)

725 "consumption") in peak intensity following the 5-day incubation, respectively. 
Biogeosciences Discuss., doi:10.5194/bg-2017-93, 2017

Manuscript under review for journal Biogeosciences

Discussion started: 22 March 2017

(C) Author(s) 2017. CC-BY 3.0 License.

\section{(c) (1)}

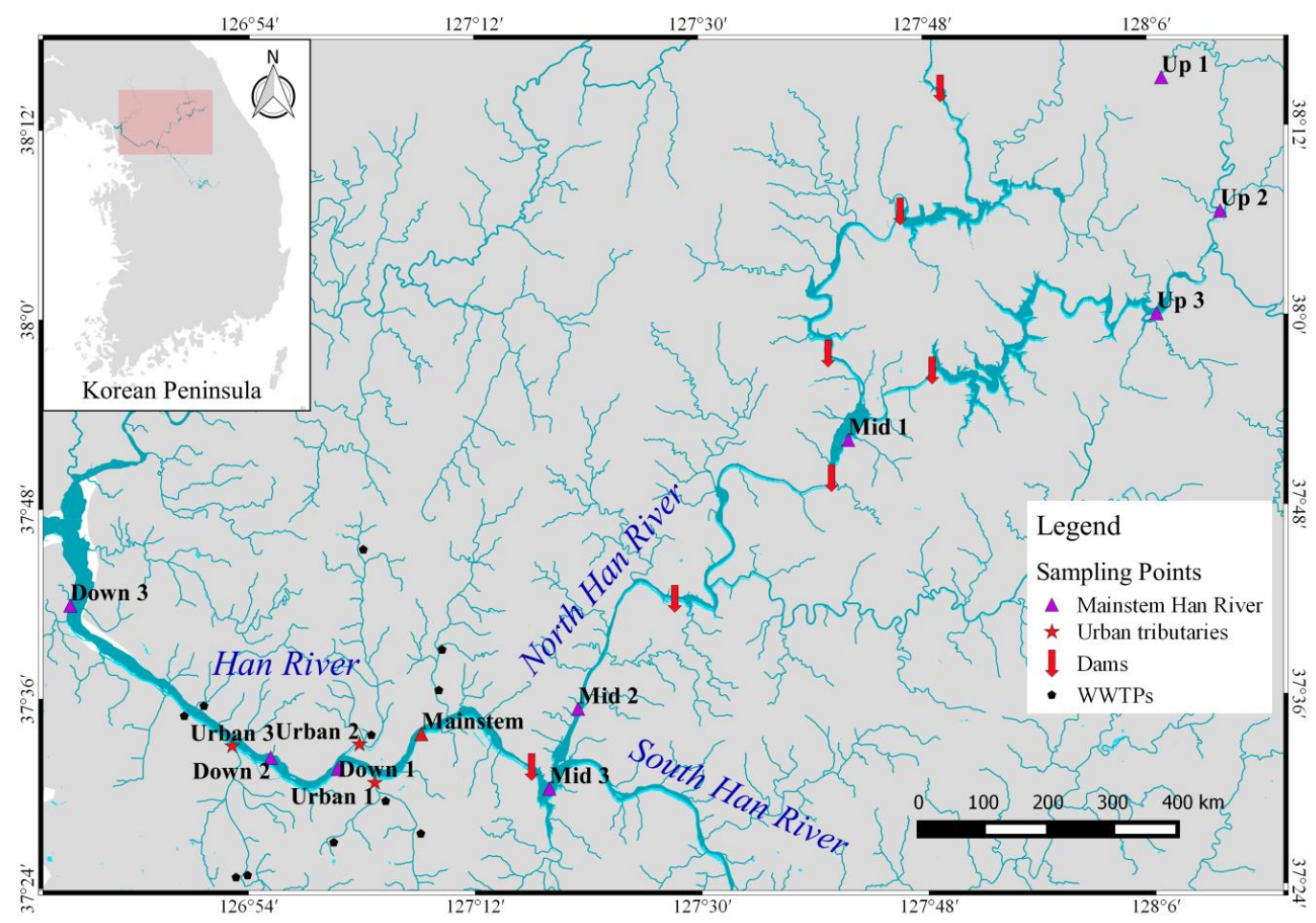

Fig. 1 
Biogeosciences Discuss., doi:10.5194/bg-2017-93, 2017

Manuscript under review for journal Biogeosciences

Discussion started: 22 March 2017

(c) Author(s) 2017. CC-BY 3.0 License.

(c) (1)

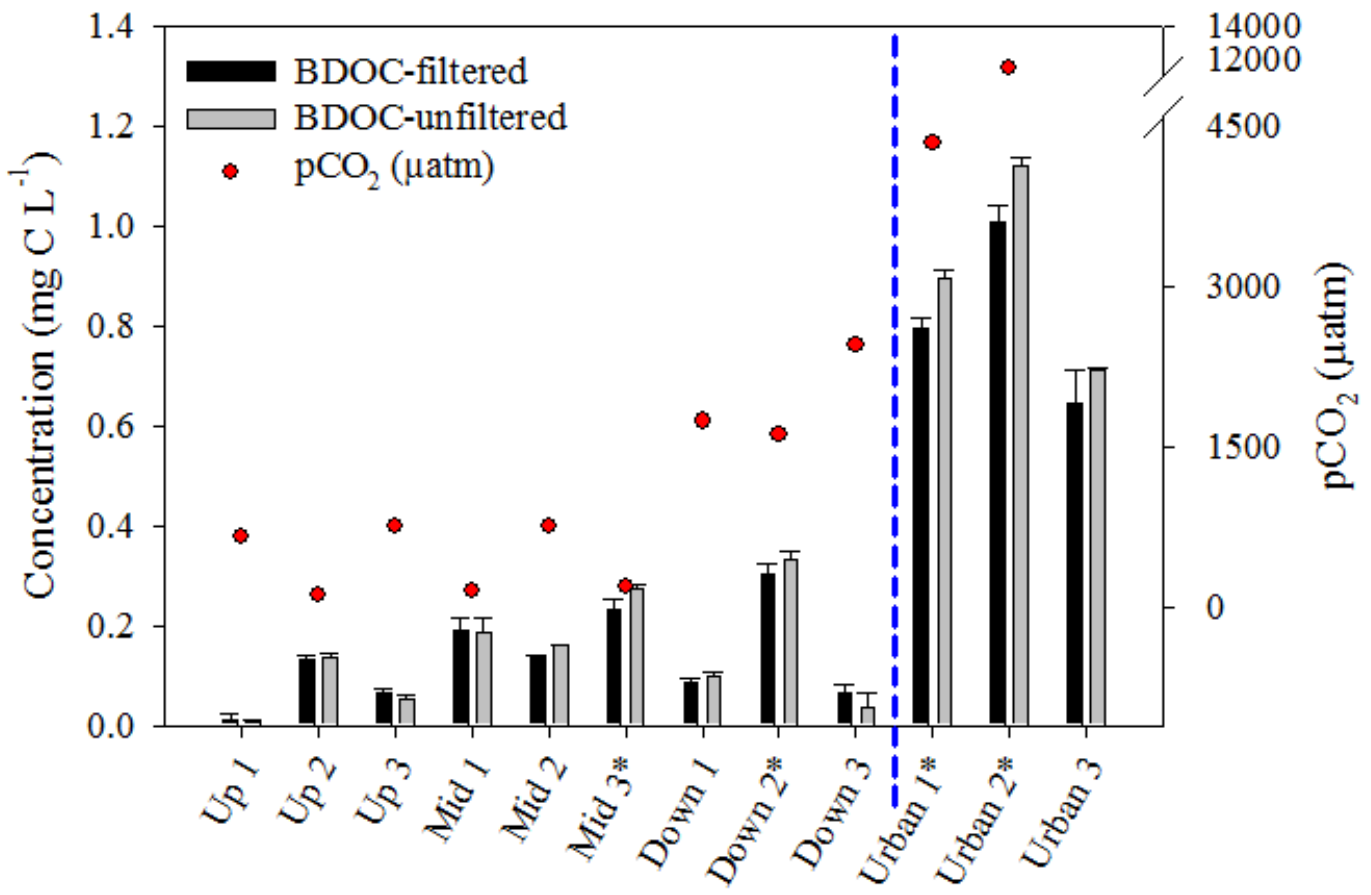

729

Fig. 2 
Biogeosciences Discuss., doi:10.5194/bg-2017-93, 2017

Manuscript under review for journal Biogeosciences

Discussion started: 22 March 2017
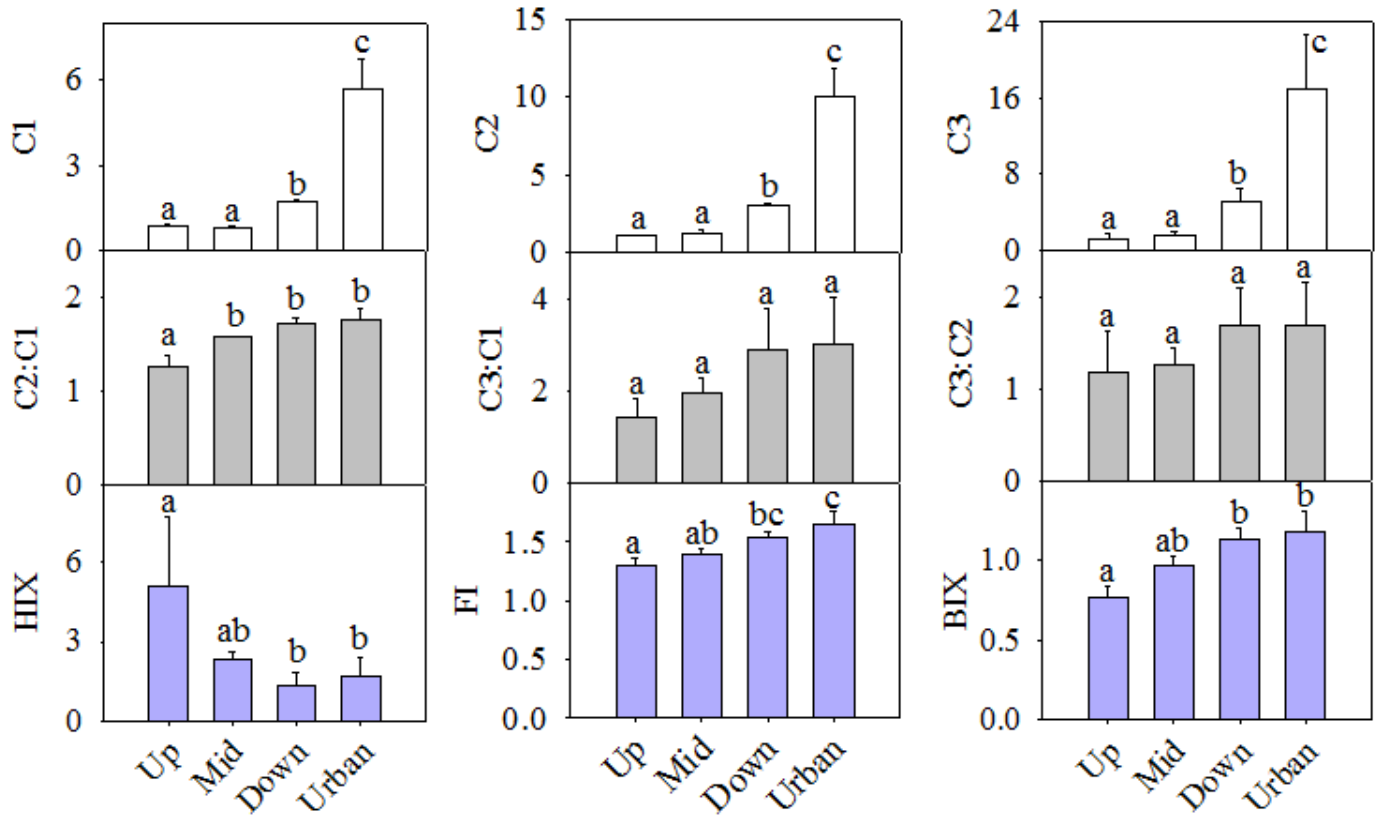

Fig. 3 
Biogeosciences Discuss., doi:10.5194/bg-2017-93, 2017

Manuscript under review for journal Biogeosciences

Discussion started: 22 March 2017

(c) Author(s) 2017. CC-BY 3.0 License.

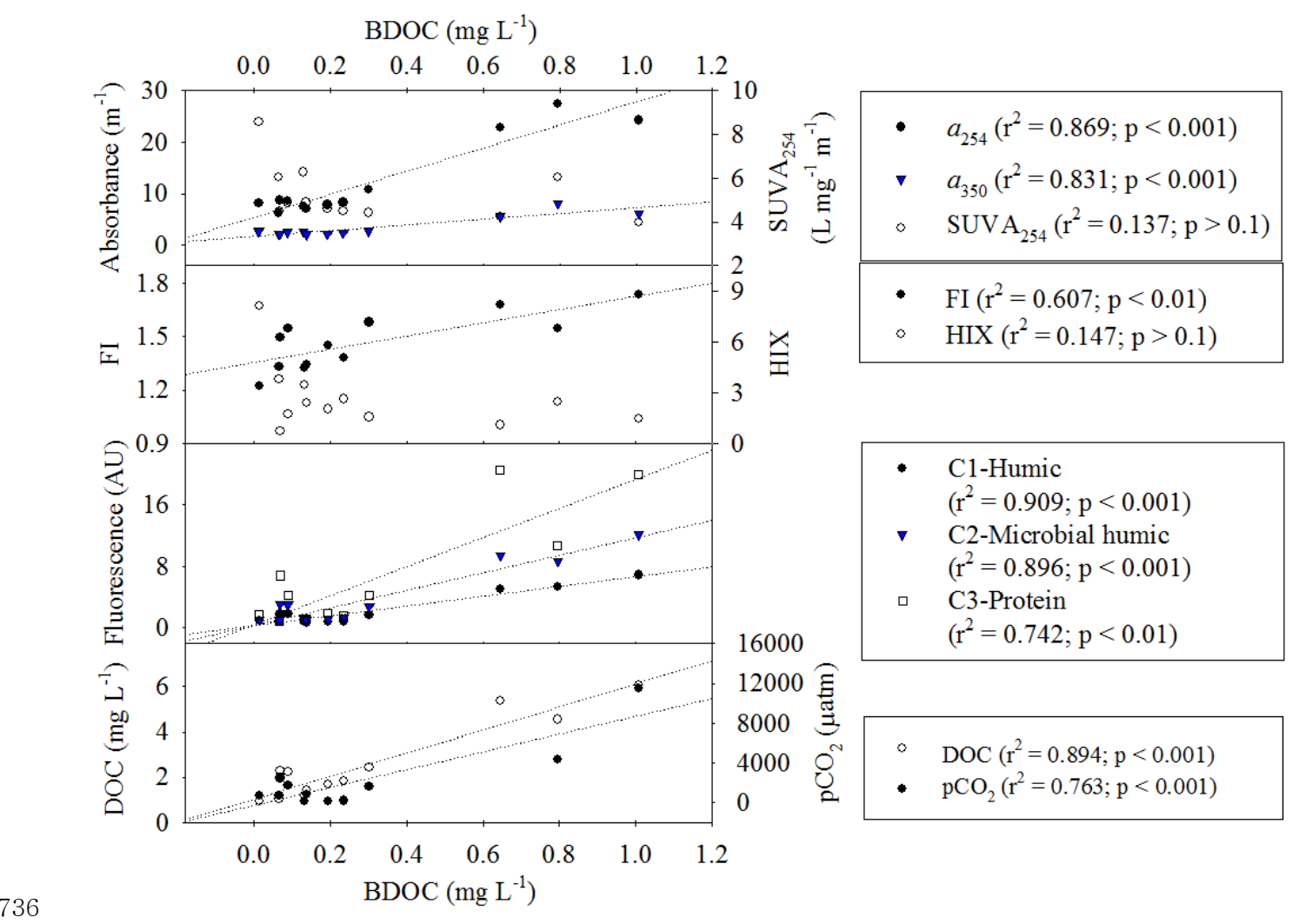

Fig. 4 
Biogeosciences Discuss., doi:10.5194/bg-2017-93, 2017

Manuscript under review for journal Biogeosciences

Discussion started: 22 March 2017

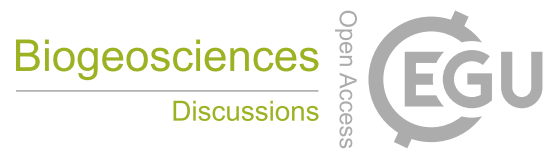

(c) Author(s) 2017. CC-BY 3.0 License.

(c) (1)

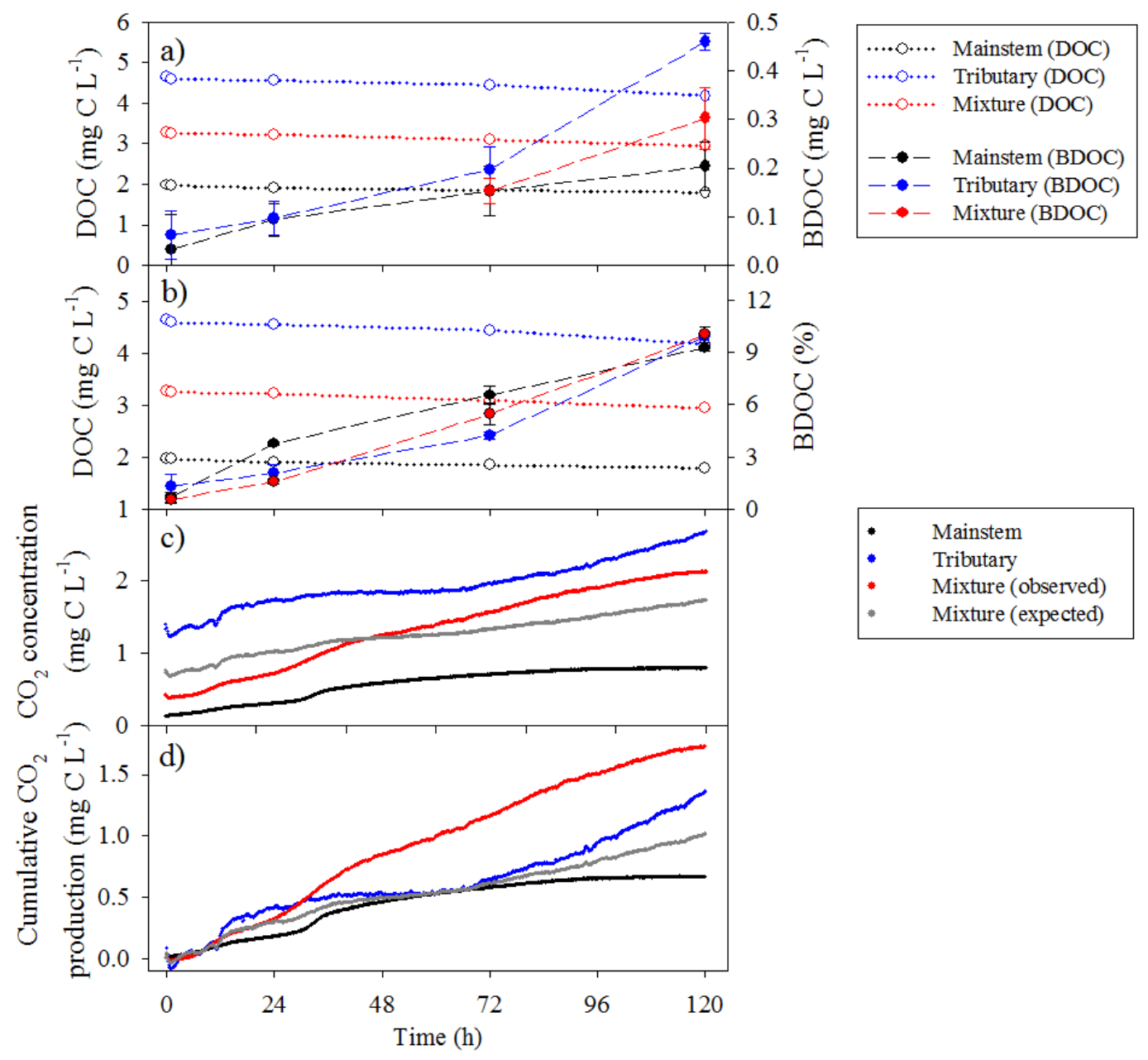

740

$741 \quad$ Fig. 5 
Biogeosciences Discuss., doi:10.5194/bg-2017-93, 2017

Manuscript under review for journal Biogeosciences

Discussion started: 22 March 2017
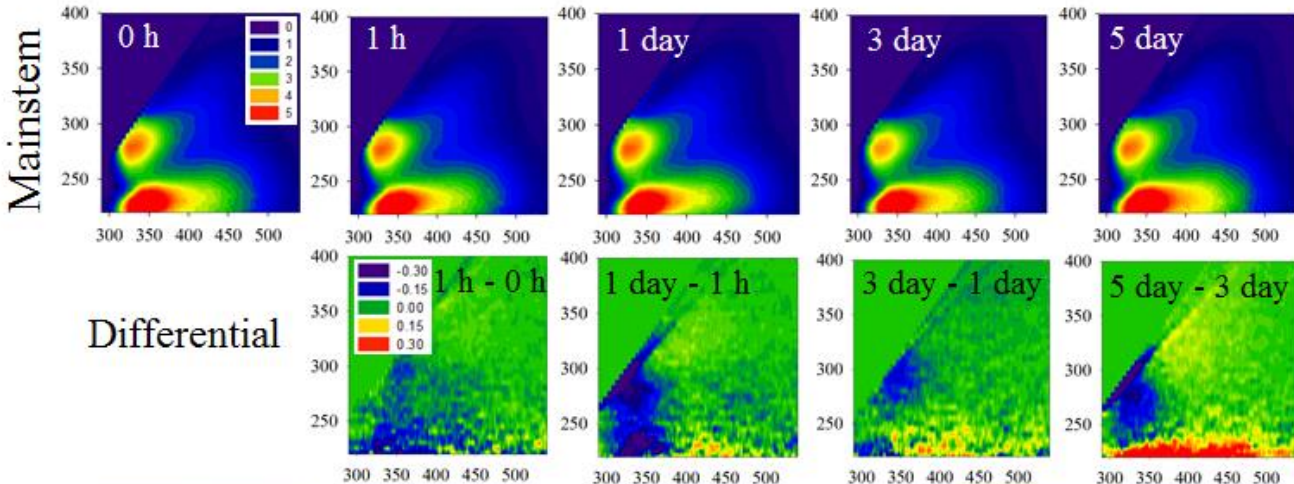

$\begin{array}{lllll}300 & 350 & 400 & 450 & 500\end{array}$

Differential
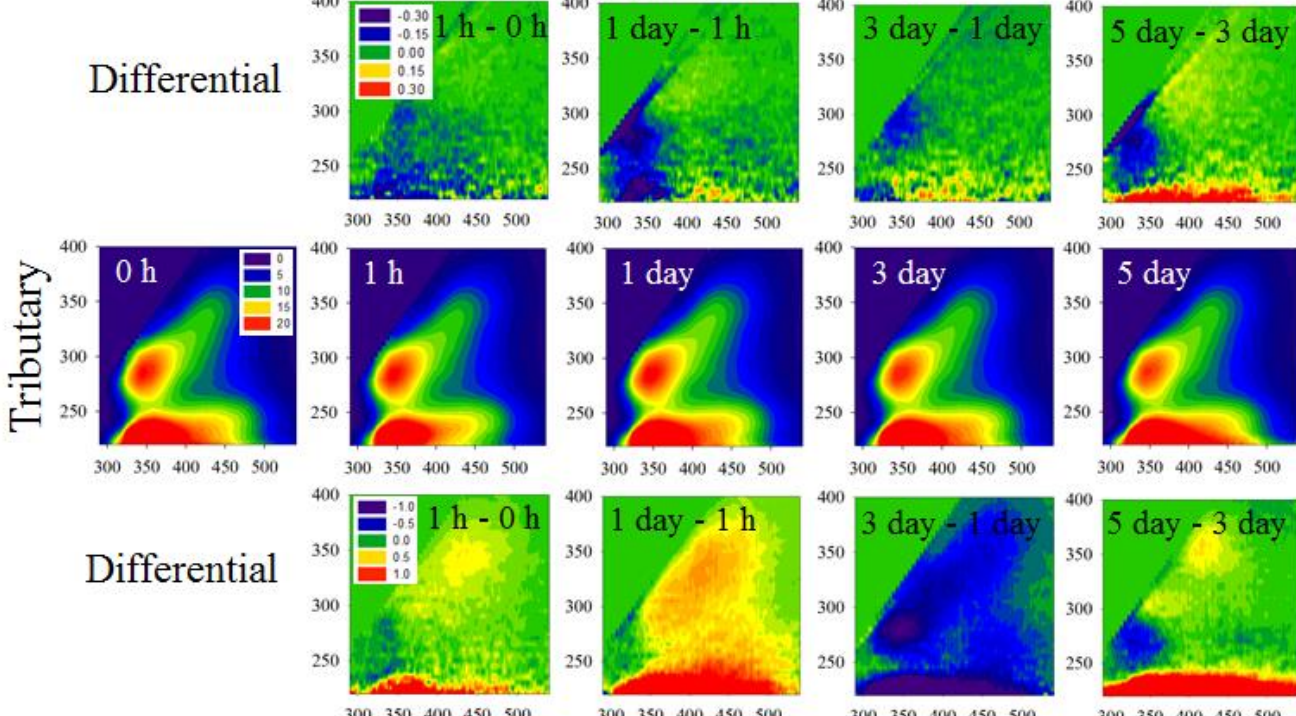

Differential
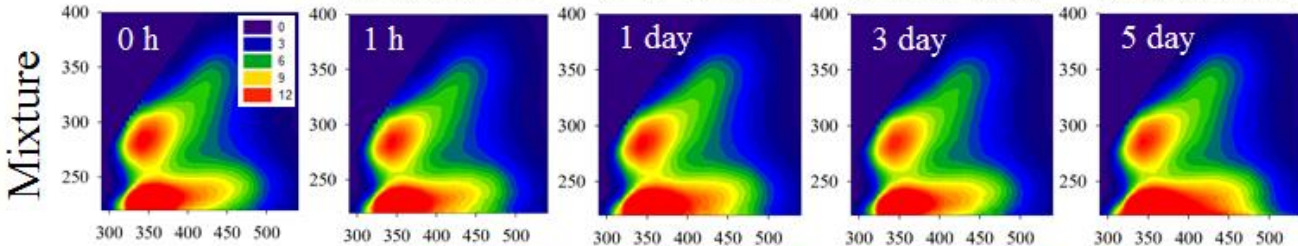

$\begin{array}{lllll}300 & 350 & 400 & 450 & 500\end{array}$

$\begin{array}{lllll}300 & 350 & 400 & 450 & 500\end{array}$
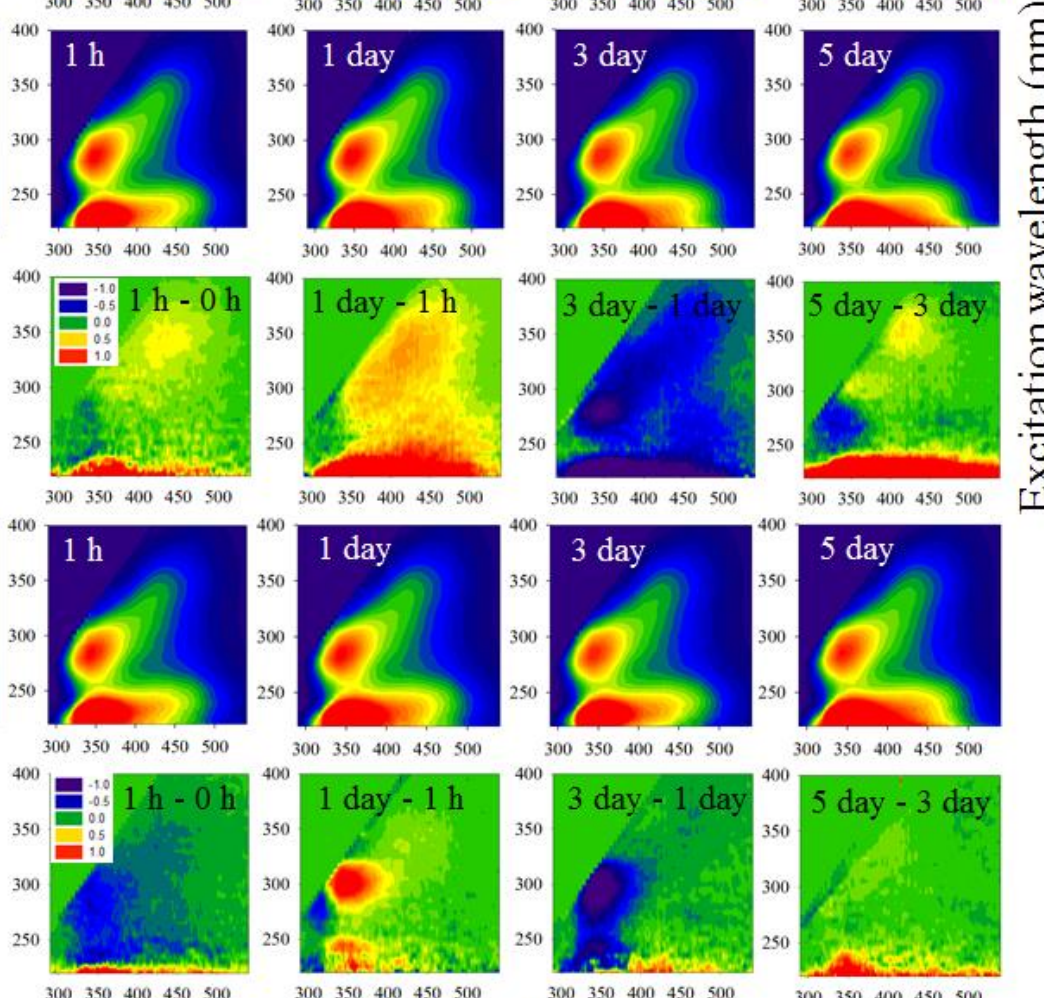

$\begin{array}{lllll}300 & 350 & 400 & 450 & 500\end{array}$

Differential Emission wavelength (nm)

Fig. 6 
Biogeosciences Discuss., doi:10.5194/bg-2017-93, 2017

Manuscript under review for journal Biogeosciences

Discussion started: 22 March 2017

(c) Author(s) 2017. CC-BY 3.0 License.

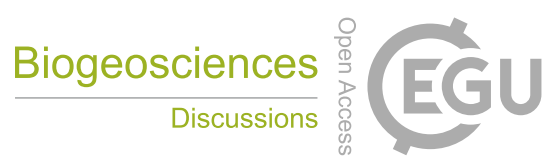

(c) (i)
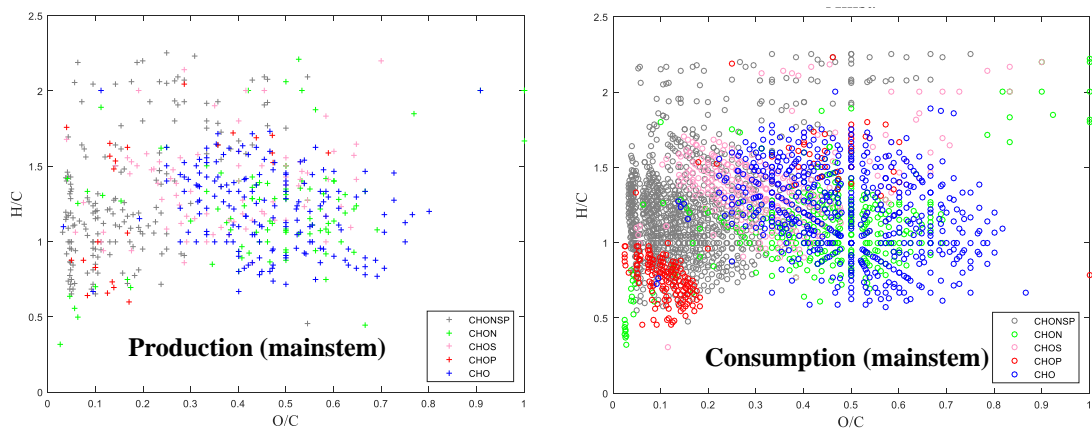

Mainstem

- Total: $\mathbf{4 7 7 5}$

- Production: 771

- Consumption: 3984
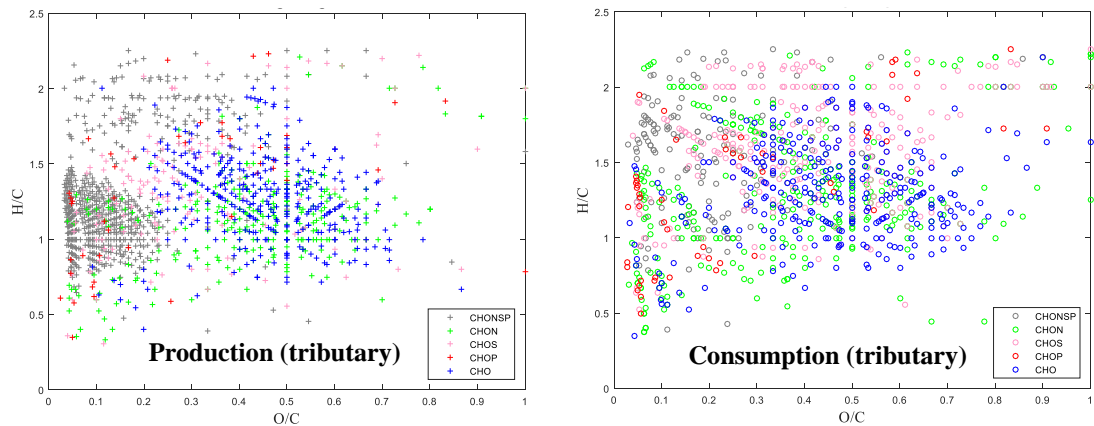

Tributary

- Total: 4286

- Production: 2789

- Consumption: 1479

Fig. 7 